
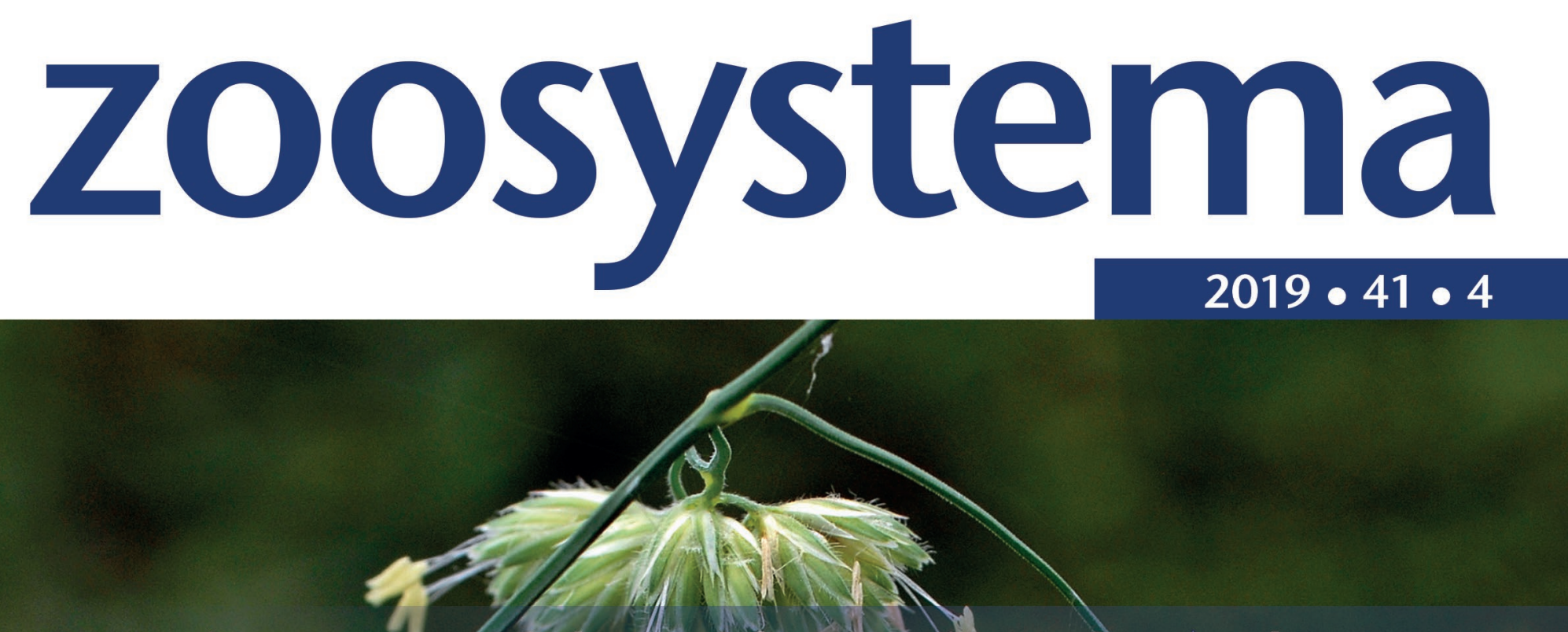

An inventory of the spider species of Barcelonnette (France), with taxonomic notes on Piniphantes agnellus $\mathbf{n}$. comb. (Araneae, Linyphiidae)

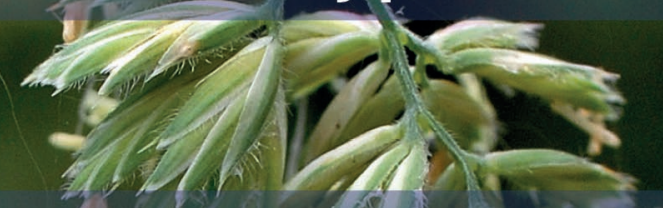

Filippo MILANO, Stefano MAMMOLA, Christine ROLLARD, Marie-France LECCIA \& Marco ISAIA

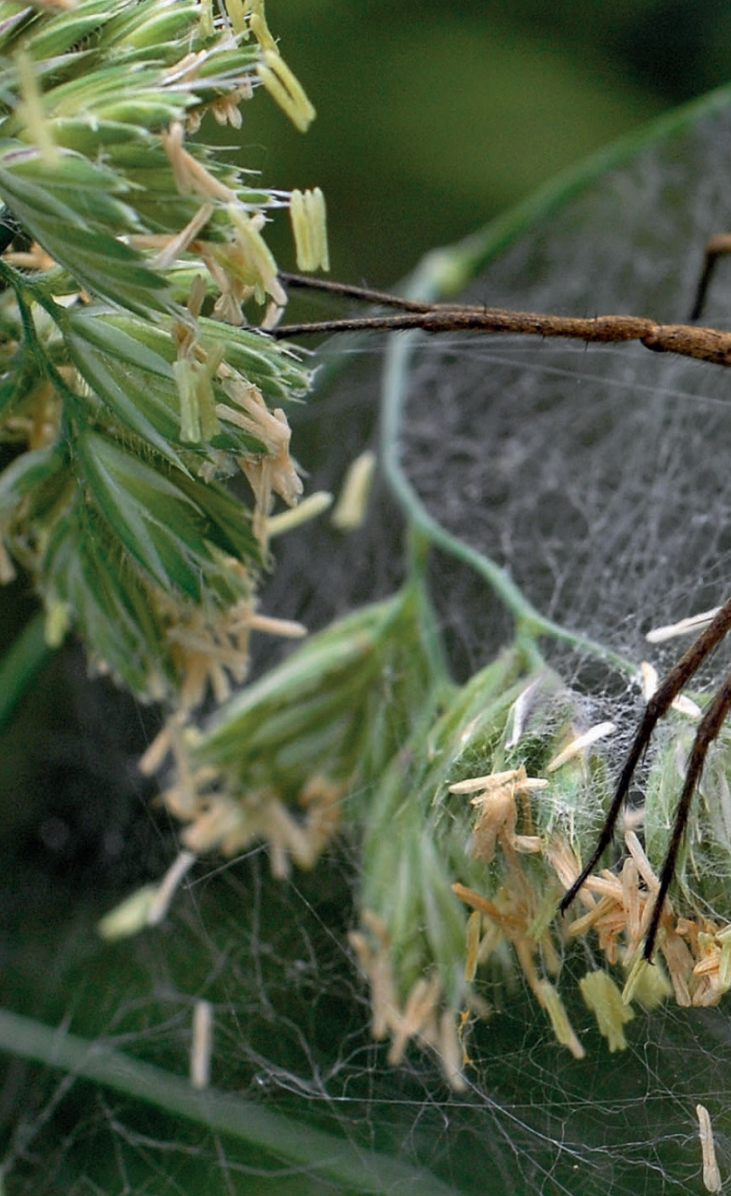

art. 41 (4) - Published on 19 February 2019 www.zoosystema.com 
DiRECTEUR DE LA PUblication: Bruno David

Président du Muséum national d'Histoire naturelle

RÉDACTRICE EN CHEF / EDITOR-IN-CHIEF: Laure Desutter-Grandcolas

AssistanTS DE RÉDACTION / AsSISTANT EDITORS: Anne Mabille (zoosyst@mnhn.fr), Emmanuel Côtez

Mise en PAge / PAge LAYOUt: Anne Mabille

COMITÉ SCIENTIFIQUE / SCIENTIFIC BOARD:

James Carpenter (AMNH, New York, États-Unis)

Maria Marta Cigliano (Museo de La Plata, La Plata, Argentine)

Henrik Enghoff (NHMD, Copenhague, Danemark)

Rafael Marquez (CSIC, Madrid, Espagne)

Peter Ng (University of Singapore)

Norman I. Platnick (AMNH, New York, États-Unis)

Jean-Yves Rasplus (INRA, Montferrier-sur-Lez, France)

Jean-François Silvain (IRD, Gif-sur-Yvette, France)

Wanda M. Weiner (Polish Academy of Sciences, Cracovie, Pologne)

John Wenzel (The Ohio State University, Columbus, États-Unis)

COUVERTURE / COVER:

Pisaura mirabilis (Clerck, 1757) (Pisauridae). Photo credit: Francesco Tomasinelli, Parc national du Mercantour.

Zoosystema est indexé dans / Zoosystema is indexed in:

- Science Citation Index Expanded (SciSearch ${ }^{\circledR}$ )

- ISI Alerting Services ${ }^{\circledR}$

- Current Contents ${ }^{\circledR} /$ Agriculture, Biology, and Environmental Sciences ${ }^{\circledR}$

- Scopus ${ }^{\circledR}$

Zoosystema est distribué en version électronique par / Zoosystema is distributed electronically by:

- BioOne ${ }^{\circledR}$ (http://www.bioone.org)

Les articles ainsi que les nouveautés nomenclaturales publiés dans Zoosystema sont référencés par / Articles and nomenclatural novelties published in Zoosystema are referenced by:

- ZooBank ${ }^{\circledR}$ (http://zoobank.org)

Zoosystema est une revue en flux continu publiée par les Publications scientifiques du Muséum, Paris / Zoosystema is a fast track journal published by the Museum Science Press, Paris

Les Publications scientifiques du Muséum publient aussi / The Museum Science Press also publish:

Adansonia, Geodiversitas, Anthropozoologica, European Journal of Taxonomy, Naturae, Cryptogamie sous-sections Algologie, Bryologie, Mycologie.

Diffusion - Publications scientifiques Muséum national d'Histoire naturelle

CP $41-57$ rue Cuvier F-75231 Paris cedex 05 (France)

Tél. : 33 (0)1 40794805 / Fax: 33 (0)1 40793840

diff.pub@mnhn.fr / http://sciencepress.mnhn.fr

(c) Publications scientifiques du Muséum national d'Histoire naturelle, Paris, 2019

ISSN (imprimé / print): 1280-9551/ ISSN (électronique / electronic): 1638-9387 


\title{
An inventory of the spider species of Barcelonnette (France), with taxonomic notes on Piniphantes agnellus $\mathrm{n}$. comb. (Araneae, Linyphiidae)
}

\author{
Filippo MILANO \\ Stefano MAMMOLA \\ Lab. di Ecologia - Ecosistemi terrestri, \\ Dipartimento di Scienze della Vita e Biologia dei Sistemi, \\ Università di Torino, Via Accademia Albertina, 13, I-10123 Torino (Italy) \\ Christine ROLLARD \\ Institut de Systématique, Évolution, Biodiversité (ISYEB), \\ Muséum national d'Histoire naturelle, CNRS, Sorbonne Université, EPHE, Université des Antilles \\ case postale 53, 57 rue Cuvier, F-75231 Paris cedex 05 (France) \\ Marie-France LECCIA \\ Parc national du Mercantour, \\ 23 rue d'Italie, F-06000 Nice (France) \\ Marco ISAIA \\ Lab. di Ecologia - Ecosistemi terrestri, \\ Dipartimento di Scienze della Vita e Biologia dei Sistemi, \\ Università di Torino, Via Accademia Albertina, 13, I-10123 Torino (Italy) \\ marco.isaia@unito.it (corresponding author)
}

Submitted on 19 March 2018 | Accepted on 17 July 2018 | Published on 19 February 2019

urn:Isid:zoobank.org:pub:F81B04D5-1F17-4A7C-8F48-607787ED20B6

Milano F., Mammola S., Rollard C., Leccia M.-F. \& Isaia M. 2019. - An inventory of the spider species of Barcelonnette (France), with taxonomic notes on Piniphantes agnellus n. comb. (Araneae, Linyphiidae). Zoosystema 41 (4): 29-58. https://doi.org/10.5252/zoosystema2019v41a4. http://zoosystema.com/41/4

\section{ABSTRACT}

We present an inventory of the spider species of the municipality of Barcelonnette (Alpes-de-HauteProvence, France), based on the material collected during the "Explor'Nature Barcelonnette" event, organised by the Mercantour National Park, from 30th June to 2nd July 2017. We report a total of 120 species, representing 83 genera and 25 families. For each species we provide faunistic/taxonomical remarks and detailed information about sampling localities, distribution, preferred habitat. Most of the species have a Palearctic distribution, followed by European and Holarctic chorotypes. We recorded a small percentage of endemic species, including rare elements occurring only in high-alpine habitats, such as Drassodex simoni Hervé, Roberts \& Murphy, 2009 and Vesubia jugorum (Simon, 1881). Twenty-six species are recorded for the first time in the Alpes-de-Haute-Provence Department. Two species, Chrysso nordica (Chamberlin \& Ivie, 1947) and Urozelotes trifidus Tuneva, 2003, are recorded for the first time

KEY WORDS

South-Western Alps,

Explor'Nature,

Mercantour National Park,

faunistics,

biodiversity,

new combination. in France. The sampling carried out in wet grasslands provided the highest number of species, followed by riparian habitats and shrublands. In addition, we provide a revision of the taxonomic position of Piniphantes agnellus (Maurer \& Thaler, 1988) n. comb., including the first description of the male and illustrations of the palp morphology. Remarks on the ecology of the species and new drawings of the female genitalia are also given. Although the biological diversity of the study area is largely unknown, this faunal inventory enhances the knowledge of the biological richness of the area of Barcelonnette. 


\author{
MOTS CLÉS \\ Alpes du Sud-Ouest, \\ Explor'Nature, \\ Parc national du Mercantour, \\ faunistique, \\ biodiversité, \\ combinaison nouvelle.
}

\begin{abstract}
RÉSUMÉ
Un inventaire des espèces d'araignées de Barcelonnette (France), avec une note taxonomique sur Piniphantes agnellus n. comb. (Araneae, Linyphiidae).

Nous présentons un inventaire des espèces d'araignées de la commune de Barcelonnette (Alpes-deHaute-Provence, France) basé sur le matériel collecté durant l'événement «Explor'Nature Barcelonnette», organisé par le Parc national du Mercantour, qui s'est déroulé du 30 juin au 2 juillet 2017. Nous faisons état d'un total de 120 espèces, représentant 83 genres et 25 familles. Pour chaque espèce, sont fournies des informations détaillées sur les localités échantillonnées, la distribution et les habitats préférentiels ainsi que des remarques faunistiques/taxonomiques. La plupart des espèces ont une répartition paléartique, suivies des espèces européennes et holartiques. Nous avons noté un petit pourcentage d'espèces endémiques, dont des taxons rares présents uniquement dans les habitats de haute altitude, comme Drassodex simoni Hervé, Roberts \& Murphy, 2009 et Vesubia jugorum (Simon, 1881). Vingt-six espèces ont été recensées pour la première fois dans le département des Alpes de Haute-Provence. Deux espèces, Chrysso nordica (Chamberlin \& Ivie, 1947) et Urozelotes trifidus Tuneva, 2003, ont été observées pour la première fois en France. L'échantillonnage mené sur les prairies humides a fourni le plus grand nombre d'espèces, suivi par les habitats rivulaires et arbustifs. D'autre part, nous révisons la position taxonomique de Piniphantes agnellus (Maurer \& Thaler, 1988) n. comb., avec la première description du mâle et l'illustration de la morphologie de ses palpes. Des notes sur l'écologie des espèces et de nouvelles illustrations des genitalia des femelles sont également fournies. Bien que la diversité biologique de l'aire étudiée reste largement inconnue, cet inventaire faunistique a permis l'amélioration de la connaissance de la richesse biologique du territoire de Barcelonnette.
\end{abstract}

\section{INTRODUCTION}

In 2017, for the first time in the history of the French national parks, the municipality of Barcelonnette joined the Mercantour National Park. In order to improve the knowledge of the biodiversity of this district and to prove its involvement in conservation policies, the Mercantour National Park organised a summer event focused on taxonomic inventories and biodiversity awareness. The "Explor'Nature Barcelonnette" event brought together more than 50 taxonomists in the newly annexed territories of the Park to study the biodiversity of the area, with special focus on the lesser known taxa. During this event, scientists worked relentlessly to record the highest number of taxa in all available habitats, from stream beds to the highest summits. Local people were also involved in the event, with field-trips lead by taxonomists and evening events aiming at sharing the results of the fieldwork carried out during the day.

This kind of event was a good example of collaboration between scientists, managers of the protected area, administrative representatives and the local population. The success of the event has led the Mercantour National Park to organise more "Explor'Nature" events in other municipalities included in its territory, especially for those participating in the "Atlas de la Biodiversité des Communes" program (ABC, "District Biodiversity Atlas" in english).

The present work represents the outcome of the field activities carried out by our team of arachnologists. We present the first inventory of the spider species (Arachnida, Araneae) of the Barcelonnette municipality, based on the material collected by the authors from 30th June to 2nd July 2017. Furthermore, we provide new taxonomic information on a species of Linyphiid spider collected during the inventory, whose male was previously unknown.

\section{MATERIAL AND METHODS}

\section{STUDY AREA}

Located in the Southern French Alps, Barcelonnette is a small municipality of less than 3000 inhabitants, covering a surface of 1642 hectares, extending on the northern and the southern slopes of the river Ubaye, in a bowl-shaped basin (Fig. 1). From an administrative point of view, Barcelonnette is situated in the North-East of the Alpes-de-Haute-Provence Department, embedded in the Provence-Alpes-Côte d'Azur (PACA) Region. Its neighbouring municipalities are Saint-Pons (N-NW), Fauconde-Barcelonnette (N-NE), Enchastrayes (SE) and Uvernet-Fours (S-SW). Located in the widest portion of the Ubaye valley, near the confluence of the Ubaye and Bachelard rivers, Barcelonnette is a crossway between the region of Gap/Durance and Italy. The mountains around Barcelonnette have peaks ranging between 2800 and $3100 \mathrm{~m}$ a.s.l., and the town itself is $1132 \mathrm{~m}$ a.s.l. high. Located on the left bank of the Ubaye river, Chapeau de Gendarme is the highest peak included in the territory of the municipality, reaching $2682 \mathrm{~m}$ a.s.l. On the right bank of the river, the altitude is lower, reaching $1972 \mathrm{~m}$ a.s.l. in the locality of Rocher Blanc. The lowest altitude is $1122 \mathrm{~m}$ a.s.l., at the confluence of the Ubaye and Bachelard rivers.

The area of Barcelonnette has been the subject of many scientific activities for more than two decades, especially in the field of geomorphology (Flageollet et al. 1999; Greiving \& Angignard 2014; van Westen et al. 2014). The "Explor'Nature Barcelonnette" event has allowed other disciplines to focus on this area, and to disclose its high biological diversity.

THE SPIDER SPECIES INVENTORY OF BARCELONNETTE The inventory here presented follows in alphabetical order, for the nomenclature we referred to the latest version of the 


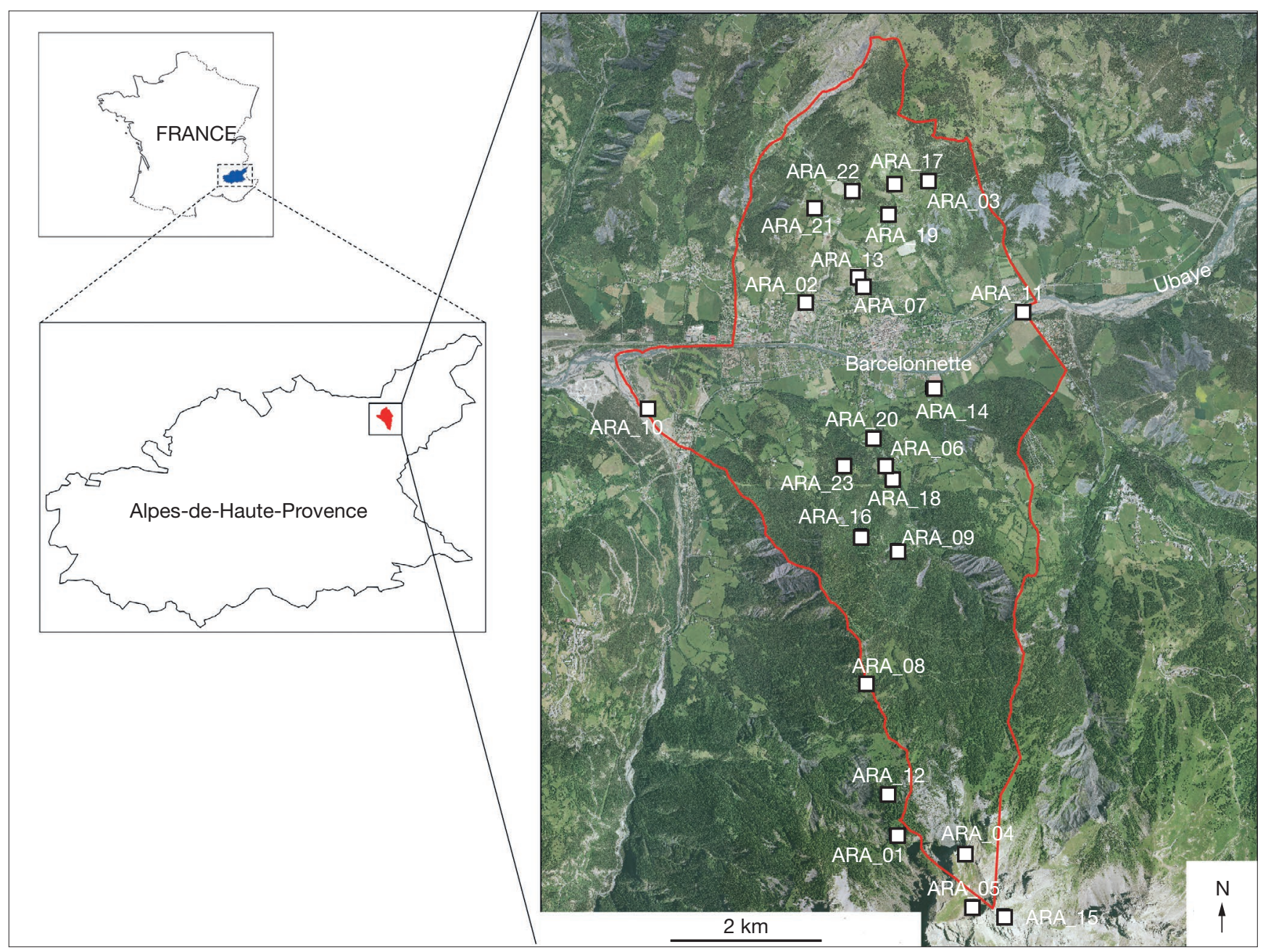

FIG. 1. - Map of the study area in the Alpes-de-Haute-Provence Department (SE France). White squares indicate the sampling localities (see Table 1). The red line represents the boundary of the municipality of Barcelonnette.

World Spider Catalog (WSC 2018). For each species we provided the list of material collected and examined (Material), the chorotype (Chorotype) and the habitat in which it was collected (Macrohabitat). When necessary, remarks and taxonomical notes were also reported (Notes). All specimens were examined and identified, whenever possible, to species level using a Leica M80 stereoscopic microscope (up to $60 \times$ magnification). Measurements were taken from digital pictures made with a Leica EC3 digital camera and calculated with the Leica LAS EZ 3.0 software (Leica Microsystems, Switzerland). All measurements are given in millimetres.

Based on the dominant land use, we grouped the sampling localities in thirteen categories of macrohabitats (Table 1): alpine grasslands, wet grasslands, alpine pastures, alpine prairies, rocky lands, broadleaved forests, coniferous forests, mixed forests, shrublands, caves, riparian habitats, ruderal areas and urban habitats. In view of the ecological continuity of the sampled habitat, we considered a buffer of $100 \mathrm{~m}$ from the boundary of the municipality, thus including in the study area a few sampling stations which are formally outside the administrative area of Barcelonnette.
"Alpine prairies" are ungrazed or lightly grazed grasslands above $1900 \mathrm{~m}$ a.s.1., while "Alpine pastures" are grazed grasslands at intermediate elevations (1600-1900 m). "Alpine grasslands" are grazed grasslands below $1600 \mathrm{~m}$ a.s.l., including dry and semi-dry alpine grasslands. "Wet grasslands" are grasslands in which springs and seepages create wet habitats, at intermediate elevations in the localities of La Salce (ARA_17) and Penelle (ARA_23). "Rocky lands" are alpine screes occurring above $2000 \mathrm{~m}$ a.s.l. Deciduous forests are included in the category "broadleaved forests". Mixed forests mainly of Populus L. and Pinus L. occurring at low/middle elevation, around $1400 \mathrm{~m}$ a.s.l., are included in the macrohabitat "mixed forests", while Abies alba Mill. woods in the Bois de Gaudissart area (ARA_16) are included in "coniferous forests". Grasslands with low vegetation and bushes are included in the category "shrublands". In this work, the category "caves" is used to classify talus caves (sensu White \& Culver 2012), i.e., caverns and crevices forming between boulders piled up on mountain slopes, found along the pathway to the Chapeau de Gendarme (ARA_01). "Riparian habitats", considered as an interface 
TABLE 1. - List of the sampling localities with corresponding macrohabitat, coordinates and altitude (see Fig. 1).

\begin{tabular}{|c|c|c|c|c|c|}
\hline Code & Locality & Macrohabitat & $\mathbf{N}$ & $\mathbf{E}$ & $\begin{array}{r}\text { Altitude } \\
\text { (m a.s.l.) }\end{array}$ \\
\hline ARA_01 & $\begin{array}{l}\text { Pathway to } \\
\text { Chapeau de } \\
\text { Gendarme }\end{array}$ & Caves & 44.3438 & 6.6530 & 2047 \\
\hline ARA_02 & Séolane Center & Urban Habitat & 44.3899 & 6.6422 & 1152 \\
\hline ARA_03 & La Salce & $\begin{array}{l}\text { Alpine } \\
\text { grasslands }\end{array}$ & 44.4005 & 6.6568 & 1535 \\
\hline ARA_04 & La Méa & Rocky lands & 44.3422 & 6.6614 & 2409 \\
\hline ARA_05 & La Méa & Rocky lands & 44.3376 & 6.6622 & 2532 \\
\hline ARA_06 & Les Amoz & Shrublands & 44.3758 & 6.6517 & 1212 \\
\hline ARA_07 & Salce basse & Shrublands & 44.3915 & 6.6488 & 1225 \\
\hline ARA_08 & Col Alaris & Alpine pastures & 44.3569 & 6.6495 & 1724 \\
\hline ARA_09 & Peiroulier & $\begin{array}{l}\text { Broadleaved } \\
\text { woods }\end{array}$ & 44.3685 & 6.6531 & 1357 \\
\hline ARA_10 & Ubaye river & $\begin{array}{l}\text { Riparian } \\
\text { habitats }\end{array}$ & 44.3807 & 6.6229 & 1120 \\
\hline ARA_11 & Ubaye river & $\begin{array}{l}\text { Riparian } \\
\text { habitats }\end{array}$ & 44.3892 & 6.6683 & 1146 \\
\hline ARA_12 & Ravin des Alaris & Alpine prairies & 44.3473 & 6.6519 & 1980 \\
\hline ARA_13 & Salce basse & $\begin{array}{l}\text { Alpine } \\
\text { grasslands }\end{array}$ & 44.3921 & 6.6484 & 1255 \\
\hline ARA_14 & La Gravette & $\begin{array}{l}\text { Alpine } \\
\text { grasslands }\end{array}$ & 44.3825 & 6.6574 & 1130 \\
\hline ARA_15 & $\begin{array}{l}\text { Chapeau de } \\
\text { Gendarme }\end{array}$ & Rocky lands & 44.3372 & 6.6548 & 2361 \\
\hline ARA_16 & $\begin{array}{l}\text { Bois de } \\
\text { Gaudissart }\end{array}$ & $\begin{array}{l}\text { Coniferous } \\
\text { forests }\end{array}$ & 44.3698 & 6.6488 & 1414 \\
\hline ARA_17 & La Salce & Wet grasslands & 44.4001 & 6.6529 & 1514 \\
\hline ARA_18 & $\begin{array}{l}\text { Chemin de } \\
\text { Gaudissard }\end{array}$ & $\begin{array}{l}\text { Riparian } \\
\text { habitats }\end{array}$ & 44.3747 & 6.6526 & 1230 \\
\hline ARA_19 & La Salce & Mixed forest & 44.3974 & 6.6522 & 1406 \\
\hline ARA_20 & Les Amoz & Shrublands & 44.3782 & 6.6502 & 1177 \\
\hline ARA_21 & Les Allemands & Ruderal areas & 44.3981 & 6.6433 & 1400 \\
\hline ARA_22 & Les Allemands & Ruderal areas & 44.3996 & 6.6478 & 1455 \\
\hline ARA_23 & Penelle & Wet grasslands & 44.3758 & 6.6466 & 1277 \\
\hline
\end{tabular}

between terrestrial and aquatic ecosystem, encompass streams and the Ubaye river banks, sometimes with the presence of pebbles. Gravel, stream banks, bushes, roadsides, stone walls, wet ditches and fallow lands occurring at two different sites in Les Allemands, at 1400 and 1455 m a.s.l. respectively, are grouped within the "ruderal areas" macrohabitat. The specimens collected in the urban area of Barcelonnette and in the vicinity of the Séolane Center (ARA_02), on walls of buildings and on urban structures, are grouped in the category "urban habitats".

We assigned chorotypes using the approach of Isaia $e t$ al. (2015) and Pantini \& Isaia (2018), referring to the works of Vigna Taglianti et al. $(1993,1999)$ and Stoch \& Vigna Taglianti (2005) (see Table 2 for the chorotype codes).

We provide the following information on the sampling event for all specimen collected: toponym of closest locality, details about habitat, altitude, date, number and sex of individuals. All specimens mentioned were collected by the authors. The specimens are preserved in $70 \%$ ethanol and the material is stored in the Marco Isaia collection (coll. MI) at the Department of Life Sciences and Systems Biology of the University of Torino and in the collection of the Muséum national d'Histoire naturelle, Paris (MNHN).
TABLE 2. - Chorotypes, relative number of species $(\mathrm{N})$ found in the study area and corresponding chorotype groups used in Fig. 15. Chorotypes follow Vigna Taglianti et al. (1993, 1999) and Stoch \& Vigna Taglianti (2005).

\begin{tabular}{lcrl}
\hline Chorotype & Abbreviation & N & Group \\
\hline Cosmopolitan & COS & 1 & Cosmopolitan \\
Holarctic & OLA & 19 & Holarctic \\
Palearctic & PAL & 43 & Palearctic \\
Sibirian-European & SIE & 17 & \\
Asiatic-European & ASE & 5 & \\
Turanic-European & TUE & 6 & Turanic-European- \\
& & & Mediterranean \\
Turanic- & TUM & 1 & \\
$\quad$ Mediterranean & & & \\
European & EUR & 15 & European \\
Southern & SEU & 1 & \\
$\quad$ European & & & \\
Central European & CEU & 1 & \\
European- & EUM & 1 & \\
$\quad$ Mediterranean & WEU & 1 & \\
Western European & MED & 1 & Mediterranean \\
Mediterranean & WME & 1 & \\
Western & & & \\
$\quad$ Mediterranean & ALPW & 3 & Endemic \\
Western Alpine & ALSW & 2 & \\
Southwestern & & & \\
$\quad$ Alpine & & &
\end{tabular}

\section{ABBREVIATIONS}

coll. MI Marco Isaia collection, Torino;

MNHN Muséum national d'Histoire naturelle, Paris.

Morphological description

AME Anterior Median Eyes;

ALE Anterior Lateral Eyes;

Mt Metatarsus;

PME Posterior Median Eyes;

PLE Posterior Lateral Eyes;

TLL Total Leg Length;

TmI position of the first metatarsal trichobothrium.

\section{RESULTS: SPIDER SPECIES INVENTORY OF BARCELONNETTE}

Family AGELENIDAE C. L. Koch, 1837

\section{Agelena labyrinthica (Clerck, 1757)}

MATERIAL. — Les Allemands, ruderal areas, 1400 m, 01.VII.2017, Rollard leg., $2 \%$, MNHN.

CHOROTYPE. — PAL.

Macrohabitat. — Ruderal areas.

\section{Coelotes pabulator Simon, 1875}

MATERiAl. — La Méa, rocky lands, 2409 m, 02.VII.2017, Isaia \& Mammola leg., 3 \%, coll. MI.

CHOROTYPE. - ALPW.

MACrohabitat. — Rocky lands. 


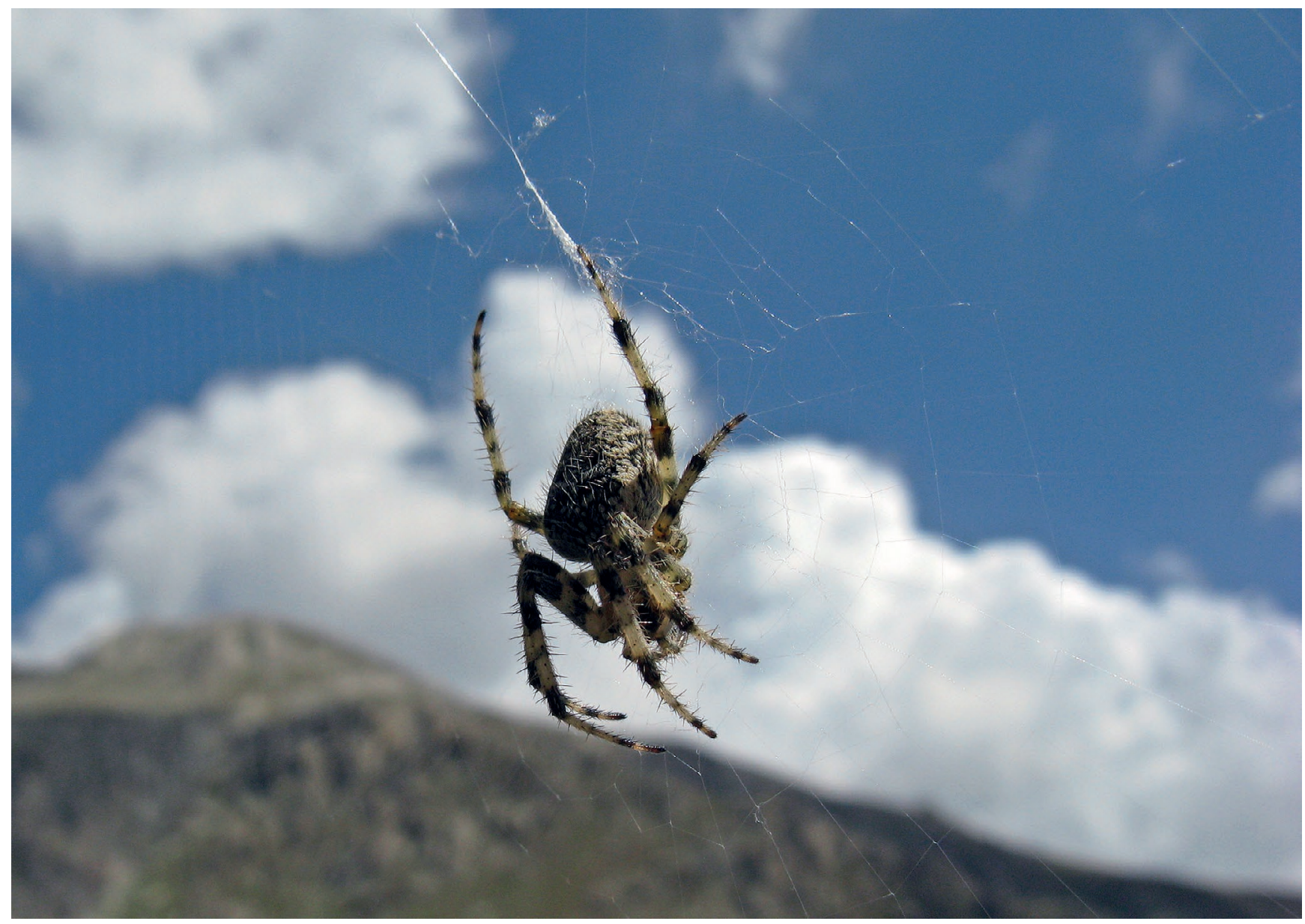

FIG. 2. - Aculepeira carbonaria (L. Koch, 1869) (Araneidae). Average body length of the female: 15.5 mm. Photo credit: Raphaële Charmetant, Parc national du Mercantour.

NoTE. - Endemic species of the Western Alps, occurring preferably at higher altitudes under stones, in screes and alpine prairies with rocky debris.

\section{Eratigena fuesslini (Pavesi, 1873)}

Material. - Ubaye river, dry riverbed with pebbles, $1146 \mathrm{~m}$, 30.VI.2017, Isaia, Mammola \& Milano leg., 1 \%, coll. MI.

Chorotype. - EUR.

MACROHABITAT. — Riparian habitats.

\section{Textrix denticulata (Olivier, 1789)}

MATERIAL. - Ubaye river, dry riverbed with pebbles, $1146 \mathrm{~m}$,

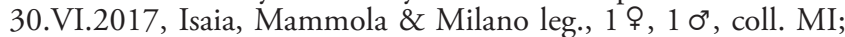
Chemin de Gaudissard, stream, 1230 m, 01.VII.2017, Isaia, Mammola \& Milano leg., 1 ㅇ, MNHN.

Chorotype. - EUR.

MACROHABITAT. - Riparian habitats.
Family AmaurobiddaE Thorell, 1870

Amaurobius ferox (Walckenaer, 1830)

Material. - Bois de Gaudissart, Silver fir woods, $1414 \mathrm{~m}$, 01.VII.2017, Isaia, Mammola \& Milano leg., 1 \%, coll. MI; La Salce, mixed forest of Populus and Pinus, 1406 m, 01.VII.2017, Isaia, Mammola \& Milano leg., 1 \%, coll. MI.

Chorotype. - OLA.

MACROHABITAT. - Coniferous forests, mixed forests.

Family ANYPHAENIDAE Bertkau, 1878

Anyphaena accentuata (Walckenaer, 1802)

MATERIAL. - Bois de Gaudissart, Silver fir woods, $1414 \mathrm{~m}$, 01.VII.2017, Isaia, Mammola \& Milano leg., 1 juv., coll. MI; Chemin de Gaudissard, stream, 1230 m, 01.VII.2017, Isaia, Mammola \& Milano leg., 3 juv., coll. MI.

Chorotype. - TUE.

MaCrohabitaT. - Coniferous forests, riparian habitats. 
Family ARANEIDAE Clerck, 1757

Aculepeira carbonaria (L. Koch, 1869)

(Fig. 2)

MATERiAL. — La Méa, rocky lands, 2409 m, 02.VII.2017, Isaia \& Mammola leg., 4 juv., coll. MI.

Chorotype. - PAL.

MACROHABITAT. — Rocky lands.

NoTE. - High alpine species, generally occurring at high elevation in rocky lands.

Aculepeira ceropegia (Walckenaer, 1802)

(Fig. 3)

MATERIAL. — La Salce, xeric grasslands, 1535 m, 01.VII.2017, Isaia, Mammola \& Milano leg., 1 \%, coll. MI; Les Amoz, low vegetation, 1212 m, 01.VII.2017, Isaia, Mammola \& Milano leg., 1 1 , $10^{\prime \prime}$, MNHN; La Salce, wet grasslands, 1514 m, 01.VII.2017, Isaia, Mammola \& Milano leg., 3 +, coll. MI; Les Allemands, ruderal areas, 1400 m, 01.VII.2017, Rollard leg., 2 \& 2 juv., MNHN; Les Allemands, ruderal areas, 1455 m, 01.VII.2017, Rollard leg., 1 ㅇ, MNHN; Ubaye river, river banks, 1120 m, 02.VII.2017, Milano leg., 2 \%, coll. MI.

Chorotype. - PAL.

MACROHABITAT. - Alpine grasslands, shrublands, wet grasslands, ruderal areas, riparian habitats.

\section{Araneus diadematus Clerck, 1757}

MATERIAL. — Les Amoz, grasslands with bushes, 1177 m, 30.VI.2017, Rollard leg., 1 juv., MNHN.

Chorotype. - OlA.

MACROHABITAT. — Shrublands.

\section{Araniella cucurbitina (Clerck, 1757)} (Fig. 4)

MAterial. — La Salce, xeric grasslands, 1535 m, 01.VII.2017, Isaia, Mammola \& Milano leg., $1 \%$, MNHN; La Salce, wet grasslands, 1514 m, 01.VII.2017, Isaia, Mammola \& Milano leg., 1 \%, coll. MI; Les Allemands, ruderal areas, 1400 m, 01.VII.2017, Rollard leg., 1 \%, MNHN; Penelle, wet grasslands, 1277 m, 02.VII.2017, Rollard leg., $10^{\top}, \mathrm{MNHN}$.

Chorotype. - PAL.

MACROHABITAT. - Alpine grasslands, wet grasslands, ruderal areas.

\section{Araniella opistographa (Kulczyński, 1905)}

MATERIAL. - Ubaye river, river banks, 1120 m, 02.VII.2017, Milano leg., $10^{\prime \prime}$, coll. MI.

Chorotype. - TUE.

MACROHABITAT. - Riparian habitats.
Cyclosa conica (Pallas, 1772)

Material. - Les Amoz, wet grasslands, 1212 m, 01.VII.2017, Isaia, Mammola \& Milano leg., 1 \%, coll. MI; pathway to Chapeau de Gendarme, shrublands, 2047 m, 02.VII.2017, Isaia \& Mammola leg., 1 \%, coll. MI.

Chorotype. - OLA.

MACROHABITAT. - Wet grasslands, shrublands.

Mangora acalypha (Walckenaer, 1802)

MATERIAL. - Salce basse, xeric grasslands, 1255 m, 01.VII.2017, Isaia, Mammola \& Milano leg., 1 , MNHN; Les Allemands, ruderal areas, 1455 m, 01.VII.2017, Rollard leg., 2 \%, MNHN.

Chorotype. - PAL.

MACROHABITAT. - Alpine grasslands, ruderal areas.

\section{Neoscona adianta (Walckenaer, 1802)}

MATERIAL. — Les Allemands, ruderal areas, 1400 m, 01.VII.2017, Rollard leg., 1 \%, MNHN.

Chorotype. - PAL.

MACROHABITAT. — Ruderal areas.

\section{Nuctenea umbratica (Clerck, 1757)}

Material. - Ubaye river, dry riverbed with pebbles, $1146 \mathrm{~m}$, 30.VI.2017, Isaia, Mammola \& Milano leg., 3 \&, coll. MI; Séolane Center, on walls of buildings, $1152 \mathrm{~m}, 01$. VII.2017, Isaia, Mammola \& Milano leg., 1 \%, coll. MI.

CHOROTYPe. - SIE.

MACROHABITAT. — Riparian habitats, urban habitats.

\section{Zilla diodia (Walckenaer, 1802)}

MATERIAL. - Salce basse, xeric grasslands, 1255 m, 01.VII.2017, Isaia, Mammola \& Milano leg., 2 \%, coll. MI.

CHOROTYPe. - SIE.

Macrohabitat. - Alpine grasslands.

Note. - Uncommon species, rarely found (Nentwig et al. 2018).

\section{Family ClubIONIDAE Wagner, 1887}

Clubiona corticalis (Walckenaer, 1802)

Material. - La Salce, mixed forest of Populus and Pinus, 1406 m, 01.VII.2017, Isaia, Mammola \& Milano leg., 1 \%, coll. MI.

Chorotype. - TUE.

MacrohabitAT. — Mixed forests.

Note. - According to Nentwig et al. (2018), this species occurs preferably below $1200 \mathrm{~m}$ a.s.l. Our finding at $1400 \mathrm{~m}$ a.s.l. extends the current known altimetric distribution range of the species. 


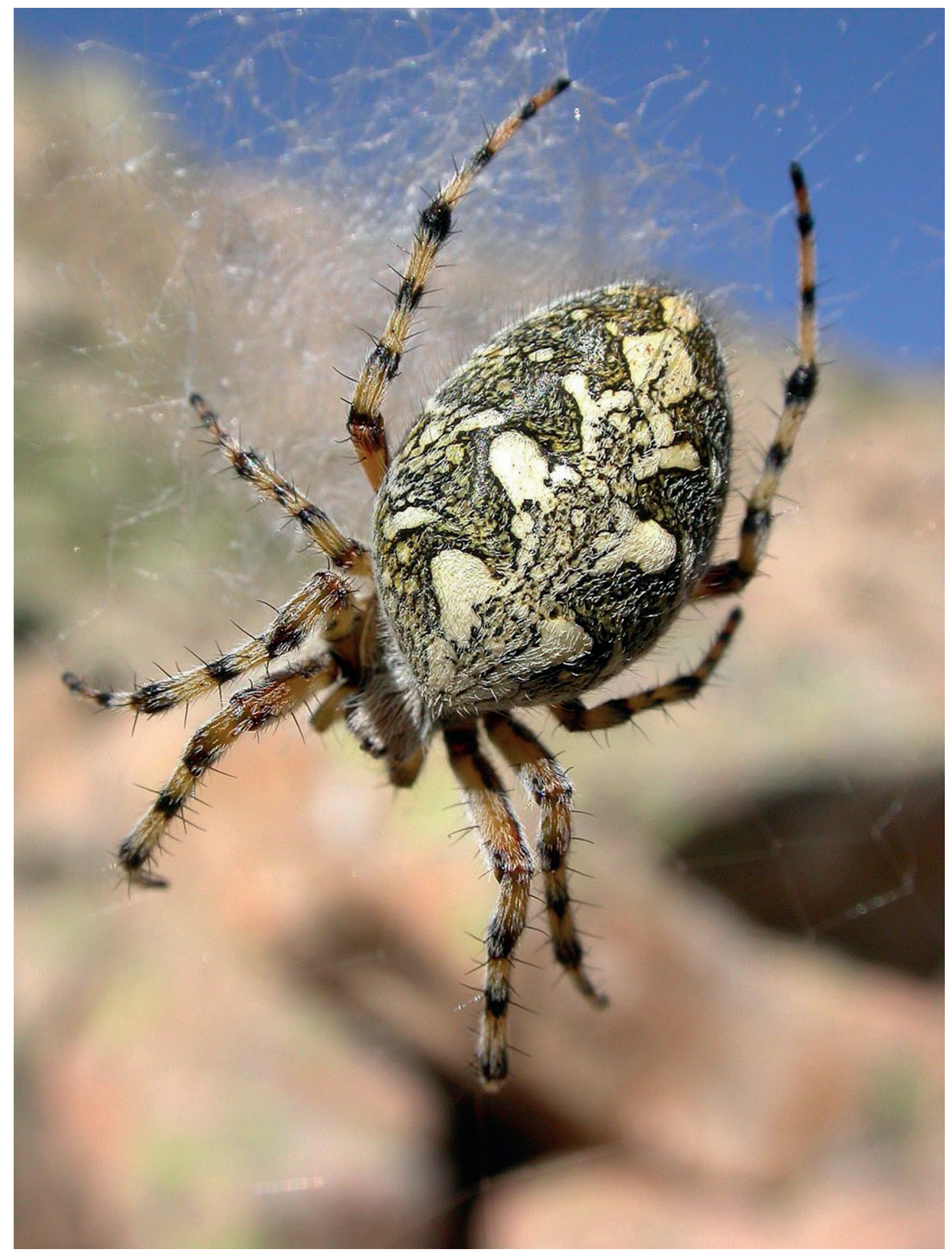

FIG. 3. - Aculepeira ceropegia (Walckenaer, 1802) (Araneidae). Average body length of the female: 13-15 mm. Photo credit: Anthony Turpaud, Parc national du Mercantour.

Family DictYNidAE O. Pickard-Cambridge, 1871

\section{Brigittea latens (Fabricius, 1775)}

MATERIAL. — Les Amoz, grasslands with bushes, 1177 m, 30.VI.2017, Rollard leg., 3 \%, $20^{7}$, MNHN; Ubaye river, river banks, $1120 \mathrm{~m}$, 02.VII.2017, Milano leg., 1 ค, 1 ơ, coll. MI.
CHOROTYPE. — SIE.

MACROHABITAT. — Shrublands, riparian habitats.

NOTE. - This species is rarely found, mostly on small bushes and low plants (Nentwig et al. 2018). 


\section{Dictyna arundinacea (Linnaeus, 1758)}

MATERIAL. — Les Allemands, ruderal areas, 1400 m, 01.VII.2017, Rollard leg., 3 \%, MNHN; Ubaye river, river banks, $1120 \mathrm{~m}$, 02.VII.2017, Milano leg., 1 \%, coll. MI; Penelle, wet grasslands, 1277 m, 02.VII.2017, Rollard leg., 2 \%, MNHN.

Chorotype. - OLA.

MACROHABITAT. - Ruderal areas, riparian habitats, wet grasslands.

\section{Dictyna pusilla Thorell, 1856}

Material. - Les Amoz, low vegetation, 1212 m, 01.VII.2017, Isaia, Mammola \& Milano leg., 1 \%, coll. MI.

CHOROTYPe. - SIE.

Macrohabitat. — Shrublands.

Nigma flavescens (Walckenaer, 1830)

MateriaL. - La Salce, wet grasslands, 1514 m, 01.VII.2017, Isaia, Mammola \& Milano leg., $10^{7}$, coll. MI.

Chorotype. - PAL.

MACROHABITAT. - Wet grasslands.

NoTE. - Foliage-dweller species, not frequent according to Nentwig et al. (2018).

\section{Family DYSDERIDAE C. L. Koch, 1837}

\section{Dysdera cribrata Simon, 1882}

MATERial. - Bois de Gaudissart, Silver fir woods, $1414 \mathrm{~m}$, 01.VII.2017, Isaia, Mammola \& Milano leg., 1 ơ, coll. MI.

Chorotype. - ALPW.

MACROHABITAT. - Coniferous forests.

Note. - Endemic, restricted to the Western Alps. See Isaia \& Chiarle (2015) for taxonomical notes and remarks on the distribution.

\section{Dysdera ninnii group}

MATERIAL. - Col Alaris, alpine pastures, 1724 m, 01.VII.2017, Isaia, Mammola \& Milano leg., 1 \%, coll. MI.

Macrohabitat. - Alpine pastures.

Note. - The identification of the species of the genus Dysdera Latreille, 1804 based only on female is hardly possible due to the similarity in female genitalic features (Deeleman-Reinhold \& Deeleman 1988; Řezáč et al. 2008).

\section{Family GNAPHOSIDAE Pocock, 1898}

\section{Drassodes lapidosus (Walckenaer, 1802)}

MATERIAL. - Ubaye river, dry riverbed with pebbles, $1146 \mathrm{~m}$, 30.VI.2017, Isaia, Mammola \& Milano leg., 1 \%, coll. MI; La Salce, xeric grasslands, $1535 \mathrm{~m}, 01$. VII.2017, Isaia, Mammola \& Milano leg., 3 \% , MNHN; Salce basse, grass with low vegetation, $1225 \mathrm{~m}$,
01.VII.2017, Isaia, Mammola \& Milano leg., 3 ㅇ, coll. MI; Salce basse, xeric grasslands, 1255 m, 01.VII.2017, Isaia, Mammola \& Milano leg., 1 \%, coll. MI; Les Allemands, ruderal areas, $1455 \mathrm{~m}$, 01.VII.2017, Rollard leg., 1 \%, MNHN; La Gravette, grasslands, 1130 m, 03.VII.2017, Isaia, Mammola \& Milano leg., 1 †, coll. MI.

Chorotype. - PAL.

MACROHABITAT. — Riparian habitats, alpine grasslands, shrublands, ruderal areas.

\section{Drassodex simoni Hervé, Roberts \& Murphy, 2009}

MATERIAL. — La Méa, rocky lands, 2409 m, 02.VII.2017, Isaia \& Mammola leg., 2 \%, coll. MI; Chapeau de Gendarme, rocky lands, 2661 m, 02.VII.2017, Isaia \& Mammola leg., 1 ㅇ, coll. MI.

CHORotyPe. - ALPW.

MACROHABITAT. - Rocky lands.

Note. - Endemic of the Maritime Alps. This species occurs in high alpine habitats, such as screes and alpine prairies. This species has recently been described by Hervé et al. (2009) from material collected in the French Maritime Alps (Mercantour National Park)

\section{Drassyllus praeficus (L. Koch, 1866)}

MATERIAL. - Salce basse, xeric grasslands, 1255 m, 01.VII.2017, Isaia, Mammola \& Milano leg., 1 \% , coll. MI; La Gravette, grasslands,

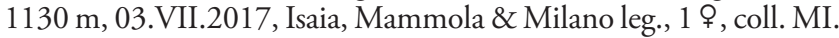

CHOROtype. - SIE.

MACROHABITAT. - Alpine grasslands.

\section{Gnaphosa lucifuga (Walckenaer, 1802)}

MATERIAL. - Salce basse, grass with low vegetation, $1225 \mathrm{~m}$, 01.VII.2017, Isaia, Mammola \& Milano leg., 1 \%, coll. MI; Les Allemands, ruderal areas, 1400 m, 01.VII.2017, Rollard leg., 1 \%, MNHN.

Chorotype. - PAL.

MACROHABITAT. — Shrublands, ruderal areas.

\section{Gnaphosa nigerrima L. Koch, 1877}

Material. - Col Alaris, alpine pastures, 1724 m, 01.VII.2017, Isaia, Mammola \& Milano leg., $1 \%$, coll. MI.

Chorotype. — PAL.

MACROHABITAT. - Alpine pastures.

Note. - Rarely found according to Nentwig et al. (2018).

Micaria formicaria (Sundevall, 1831)

Material. — La Salce, xeric grasslands, 1535 m, 01.VII.2017, Isaia, Mammola \& Milano leg., 1 \%, coll. MI; Peiroulier, broadleaved forests, 1357 m, 01.VII.2017, Isaia, Mammola \& Milano leg., 1 ơ $^{\prime \prime}$ coll. MI; La Gravette, grasslands, 1130 m, 03.VII.2017, Isaia, Mammola \& Milano leg., 1 \%, coll. MI. 


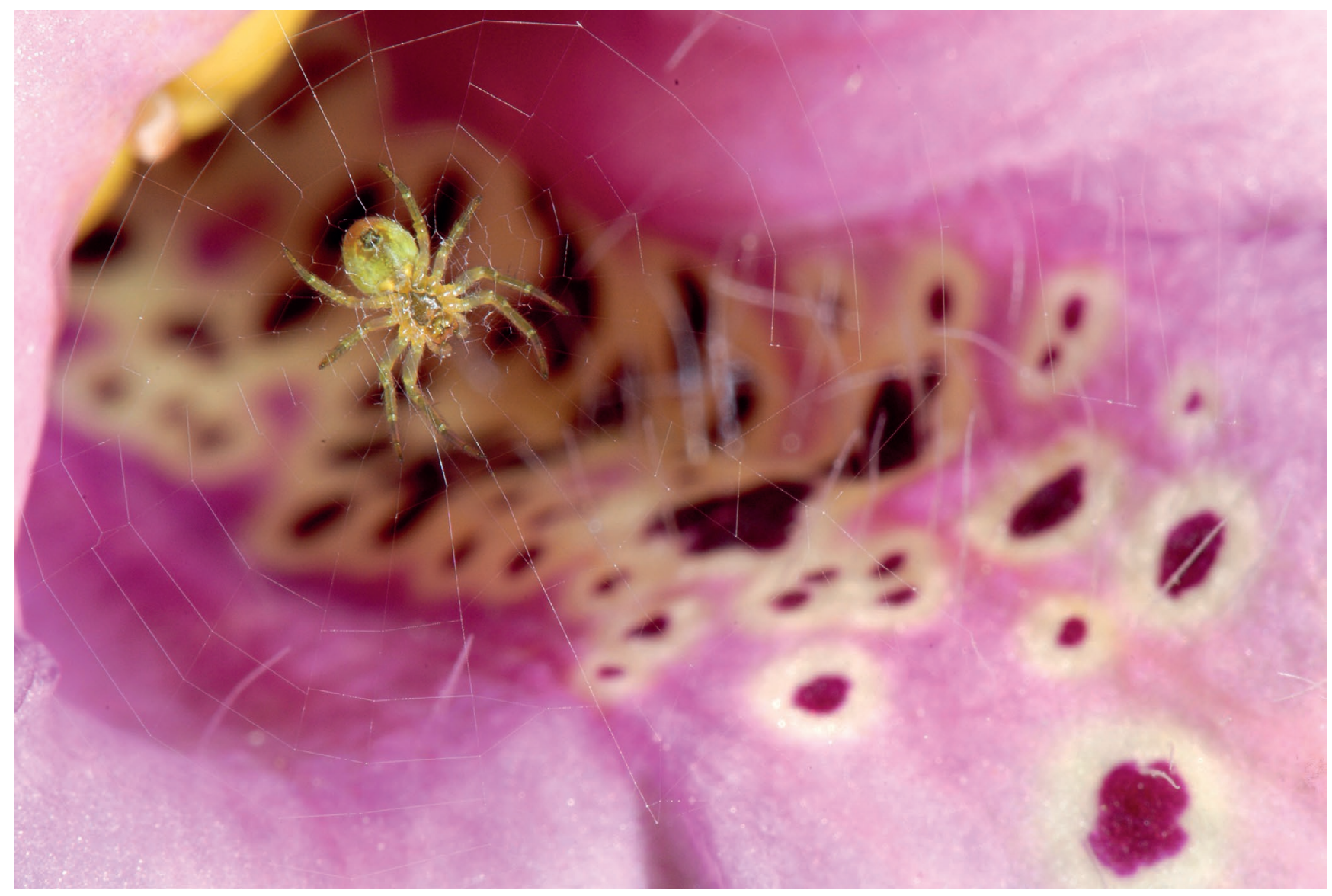

FIG. 4. - Araniella cucurbitina (Clerck, 1757) (Araneidae). Average body length of the female: 4.5-9.5 mm. Photo credit: Francesco Tomasinelli, Parc national du Mercantour.

ChorotyPe. - PAL.

MACROHABITAT. - Alpine grasslands, broadleaved forests.

Note. - This species, as many other of the genus Micaria Westring, 1851 , is an ant mimic.

\section{Trachyzelotes pedestris (C. L. Koch, 1837)}

MATERIAL. - Salce basse, xeric grasslands, 1255 m, 01.VII.2017, Isaia, Mammola \& Milano leg., 1 ㅇ, MNHN.

CHorotype. - EUR.

MACrOHABitaT. - Alpine grasslands.

\section{Urozelotes trifidus Tuneva, 2003}

(Fig. 5)

Material. - Ubaye river, dry riverbed with pebbles, $1146 \mathrm{~m}$, 30.VI.2017, Isaia, Mammola \& Milano leg., 2 \%, 1 ơ, coll. MI.

CHOROTYPe. - EUR?

MACROHABITAT. - Riparian habitats.

NoTE. - New record for France. This species was previously known exclusively for Southern Urals (Russia) (Tuneva 2003). Considering the habitat where the specimens were collected, the presence of this species in France may be regarded as an anthropogenic introduction or, alternatively, a new data of occurrence of a rare, but widely distributed species. We herein provide diagnostic drawings for the species identification (Fig. 5).

Family HAHNIIDAE Bertkau, 1878

Antistea elegans (Blackwall, 1841)

MATERIAL. - La Salce, wet grasslands, 1514 m, 01.VII.2017, Isaia, Mammola \& Milano leg., 4 ㅇ, 1 o", coll. MI.

Chorotype. - PAL.

MACROHABITAT. - Wet grasslands.

Family LINYPHIIDAE Blackwall, 1859

\section{Agyneta mollis (O. Pickard-Cambridge, 1871)}

MATERIAL. — La Gravette, grasslands, 1130 m, 03.VII.2017, Isaia,

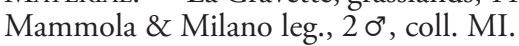

CHorotype. - ASE.

MacrohabitaT. - Alpine grasslands. 


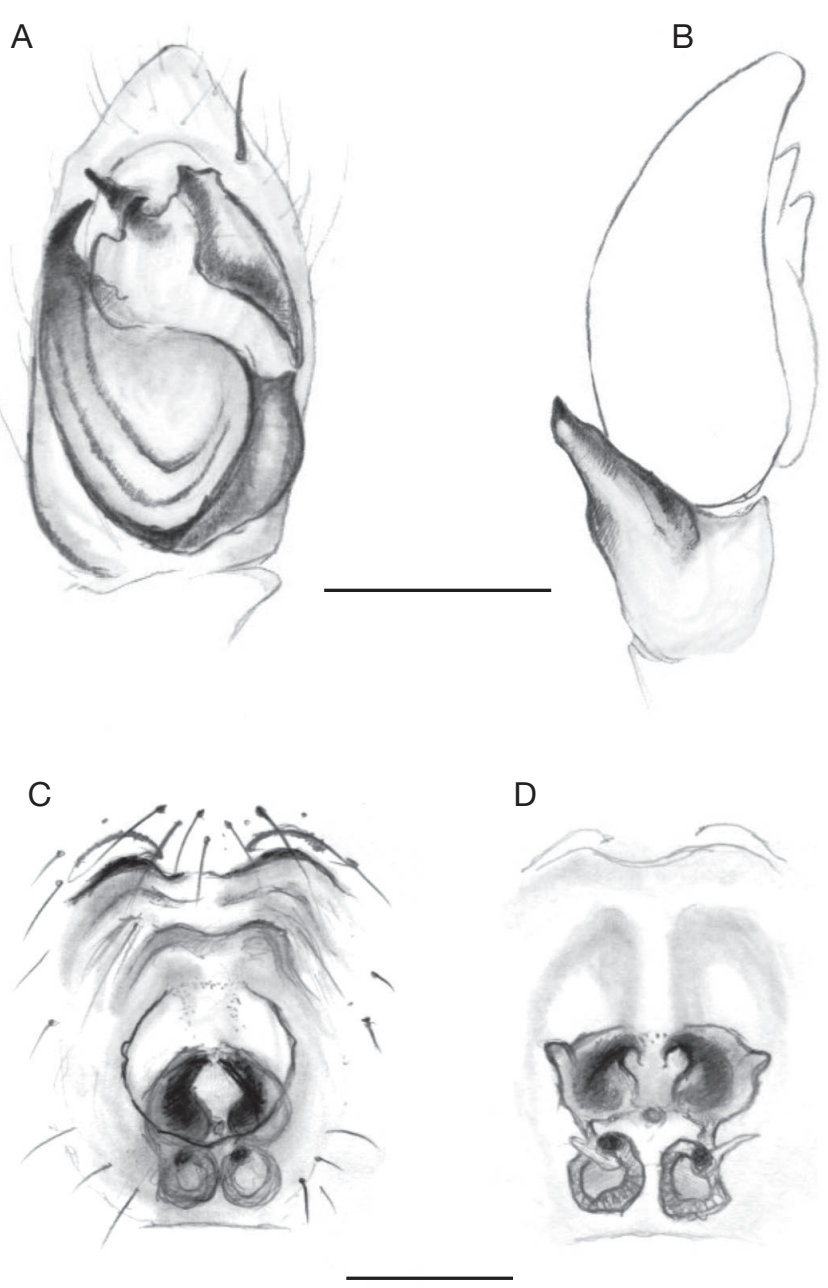

FIG. 5. - Urozelotes trifidus Tuneva, 2003 (Gnaphosidae) male (A, B) and female (C, D) from Barcelonnette (France): A, palp, ventral view; B, palp, retrolateral view; C, epigyne, ventral view; $\mathbf{D}$, vulva, dorsal view. Scale bars: $A, B, 0.25 \mathrm{~mm}$; B, C, $0.2 \mathrm{~mm}$. Illustration by Stefano Mammola

\section{Diplocephalus cristatus (Blackwall, 1833)}

MATERIAL. — La Méa, rocky lands with snow, 2532 m, 02.VII.2017, Isaia \& Mammola leg., 3 \%, 2 ơ, coll. MI.

ChOrotype. - EUR.

MACROHABITAT. - Rocky lands.

Note. - Recently, Bosmans \& Oger (2018) reconsidered the status of $D$. cristatus by defining two morphs: cristatus and foraminifer. All specimens collected here belong to the morph foraminifer. The presence of this morph in the area of Barcelonnette was already documented by Pickard-Cambridge (1875) and Simon (1926). This morph is mostly distributed in the southern part of Europe (Nentwig et al. 2018). According to Bosmans \& Oger (2018), this morph has a narrower range of specialized habitats than cristatus.
Drapetisca socialis (Sundevall, 1833)

MATERIAL. — Les Amoz, grasslands with bushes, 1177 m, 30.VI.2017, Rollard leg., 1 \%, MNHN.

Chorotype. - PAL.

MACROHABITAT. - Shrublands.

Frontinellina frutetorum (C. L. Koch, 1834)

MATERIAL. - La Salce, wet grasslands, 1514 m, 01.VII.2017, Isaia, Mammola \& Milano leg., 2 \%, coll. MI; Col Alaris, alpine pastures, 1724 m, 01.VII.2017, Isaia, Mammola \& Milano leg., 1 \%, coll. MI; Salce basse, grass with low vegetation, $1225 \mathrm{~m}, 01$.VII.2017, Isaia, Mammola \& Milano leg., 1 ○, coll. MI.

CHOrotype. - SIE.

MACROHABITAT. - Wet grasslands, alpine pastures, shrublands.

Hilaira excisa (O. Pickard-Cambridge, 1871)

MATERIAL. - La Salce, wet grasslands, 1514 m, 01.VII.2017, Isaia, Mammola \& Milano leg., 1 \% , 2 ơ, coll. MI.

Chorotype. - EUR.

MACROHABITAT. - Wet grasslands.

NoTE. - Hygrophilic species, generally found in very humid moss, in shaded habitats (Nentwig et al. 2018)

\section{Linyphia hortensis Sundevall, 1830}

Material. - La Salce, mixed forest of Populus and Pinus, 1406 m, 01.VII.2017, Isaia, Mammola \& Milano leg., 2 \%, coll. MI.

Chorotype. - PAL.

MACROHABITAT. — Mixed forests.

\section{Linyphia triangularis (Clerck, 1757)}

MATERIAL. - Les Allemands, ruderal areas, 1400 m, 01.VII.2017, Rollard leg., 2 \%, $20^{7}$, MNHN; Les Amoz, grasslands with bushes, 1177 m, 30.VI.2017, Rollard leg., 1 juv., MNHN.

CHORotype. - PAL.

MACROHABITAT. — Ruderal areas, shrublands.

\section{Neriene radiata (Walckenaer, 1841)}

Material. - Chemin de Gaudissard, stream, 1230 m, 01.VII.2017, Isaia, Mammola \& Milano leg., 1 \%, coll. MI; Les Allemands, ruderal areas, 1400 m, 01.VII.2017, Rollard leg., 1 \%, MNHN.

Chorotype. - OLA.

MaCrOHABITAT. - Riparian habitats, ruderal areas. 


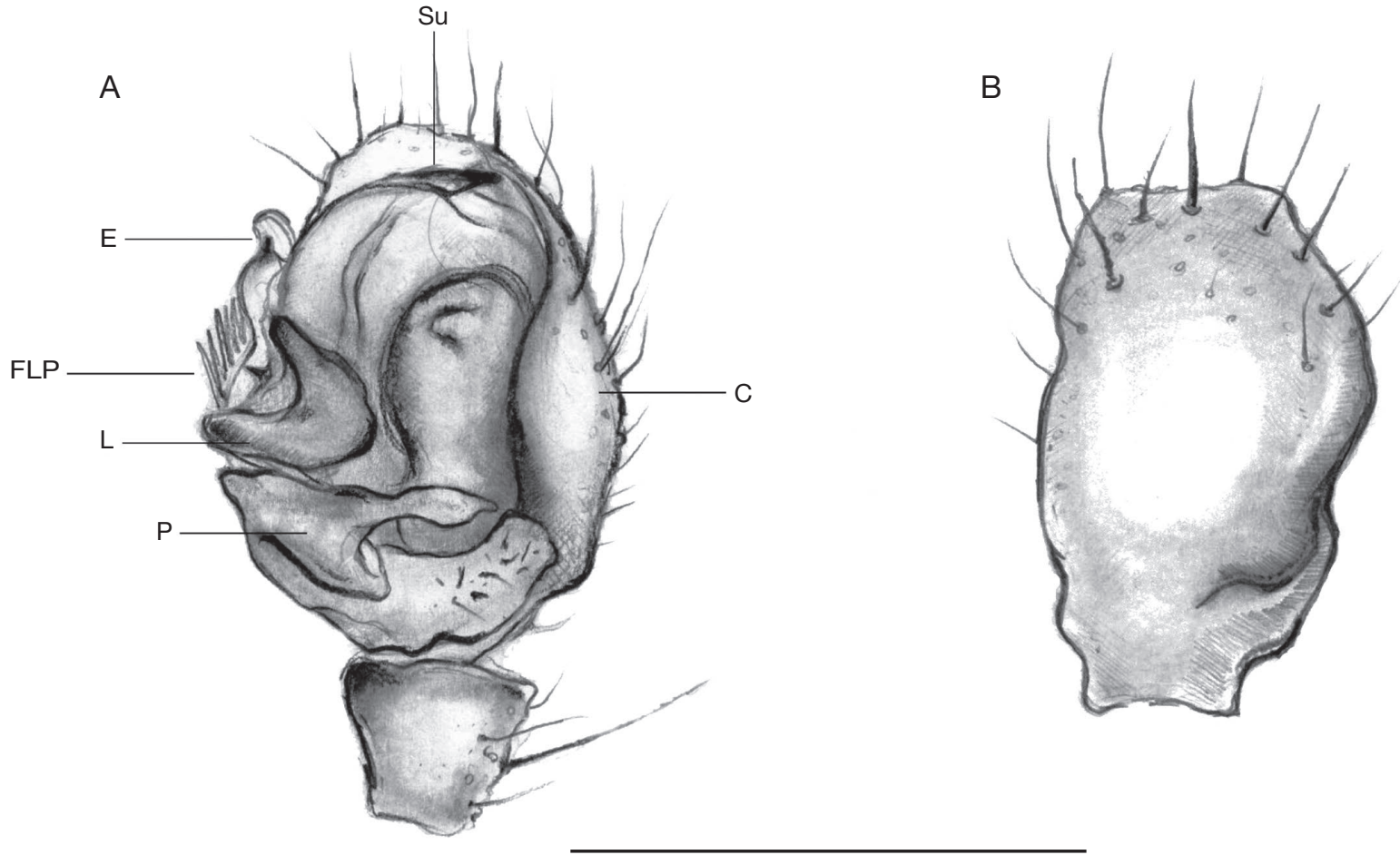

FIG. 6. - Piniphantes agnellus (Maurer \& Thaler, 1988) n. comb. (Linyphiidae): male from Valdieri (Italy): A, palp, lateral view; B, cymbium, dorsal view. Abbreviations: C, cymbium; E, embolus; FLP, finger-like protrusions; L, lamella characteristica; P, paracymbium; Su, distal suprategular apophysis. Scale bar: 0.12 mm. Illustration by Stefano Mammola.

Piniphantes agnellus (Maurer \& Thaler, 1988) n. comb. (Figs 6, 7, 8)

Lepthyphantes agnellus Maurer \& Thaler, 1988: 338, figs 17-19.

Material. - France. Provence-Alpes-Côte d'Azur, Alpes-de-HauteProvence, Barcelonnette, pathway to Chapeau de Gendarme, talus caves, 2047 m, 02.VII.2017, Isaia \& Mammola leg., 9 \%, coll. MI.

OTher MATERIAL. - Italy. Piemonte, Province of Cuneo, Valdieri, Galleria di Valscura, alpine scree, 2100 m, 12.VII.2009, Isaia leg., 1 ơ $^{7}$ (sub L. agnellus in Isaia et al. 2015; coll. MI); Piemonte, Province of Cuneo, Valdieri, Lago Soprano della Sella, alpine prairies with rocky debris, $2300 \mathrm{~m}, 01$.VIII.2011, Chiarle leg., 1 \% (sub L. agnellus in Isaia et al. 2015; coll. MI); Piemonte, Province of Torino, Cesana, Champlas Janvier, grasslands, 2200 m, VII.2011, Chamberlain leg., $10^{\pi}$, coll. MI; Piemonte, Province of Cuneo, Vinadio, Colle della Lombarda, rocky lands, 2600 m, 06.VI.2016, Isaia leg., 1 \&, coll. MI; Piemonte, Province of Cuneo, Terme di Valdieri, pathway to Fremamorta, alpine prairies with rocky debris, $2200 \mathrm{~m}$, 11.VI.2016, Isaia leg., 3 \%, coll. MI; Piemonte, Province of Cuneo, S. Anna di Vinadio, Fortini Laghi Lausfer, alpine prairies with rocky debris, 2300 m, 20.VII.2016, Isaia, Mammola \& Milano leg., 13 \%, coll. MI; Liguria, Province of Imperia, Pigna, Monte Grai, abandoned mine, 1903 m, 12.VIII.2016, Isaia \& Beikes leg., 1 o", 4 \% coll. MI; Piemonte, Province of Cuneo, Ormea, Monte Mongioie, alpine prairies with rocky debris, 1950-2100 m, 03.X.1972, Thaler leg., 5 \% (Maurer \& Thaler 1988) (not examined).

France. Provence-Alpes-Côte d'Azur, Alpes-Maritimes, Belvédère, Pas de l'Arpette, rocky debris, 2400 m, 01.VIII.1986, Maurer leg., 1 ? (Maurer \& Thaler 1988) (not examined); Provence-Alpes-Côte
d'Azur, Alpes-Maritimes, Tende, Vallée des Merveilles, next to Lac Mouton, alpine scree with vegetation, $2190 \mathrm{~m}$, 10.VIII.2004, Hervé \& Gargominy leg., 2 \%, ARM002, MNHN; Provence-AlpesCôte d'Azur, Alpes-Maritimes, Belvédère, next to Lac Autier, alpine scree, 2400 m, 12.VIII.2004, Hervé leg., 1 \&, ARM016, MNHN; Provence-Alpes-Côte d'Azur, Alpes-Maritimes, Tende, La Minière de Vallauria, waterfall scree, 1508 m, 13.VI.2005, Hervé leg., 2 ㅇ, ARM061, MNHN; Provence-Alpes-Côte d'Azur, Alpes-de-HauteProvence, Allos, Sommets des Garrets, western slope, alpine scree, 2670 m, 08.IX.2005, Hervé leg., 2 \% 1 o", ARM139, MNHN.

\section{CHOrotype. - ALSW.}

MACROHABITAT. - Caves, rocky lands.

NOTE. - The collection of this rare species in the frame of this work give us the opportunity to clarify its taxonomic position and to describe the so far unknown male, collected in the frame of previous researches. We hereby provide an exhaustive taxonomical note and information about its current known distribution and provide new diagnostic drawings for male and female (Figs 6, 7, 8).

Type MATERIAL. - Holotype, female. Leg. Maurer 06.VIII.1986, Museum of Natural History of Genève (not examined).

TyPE LOCALITY. - Boulder fields in the vicinity of Lac de l'Agnel (Tende, France), Alpes-Maritimes, 2530 m, in rock field.

\section{DESCRIPTION OF THE MALE}

(Specimen from Valdieri, Galleria Valscura): overall size and leg length small. Prosoma 0.49 long, 0.40 wide, light-yellowish. Thoracic region yellowish with grey shades. Cephalic region 

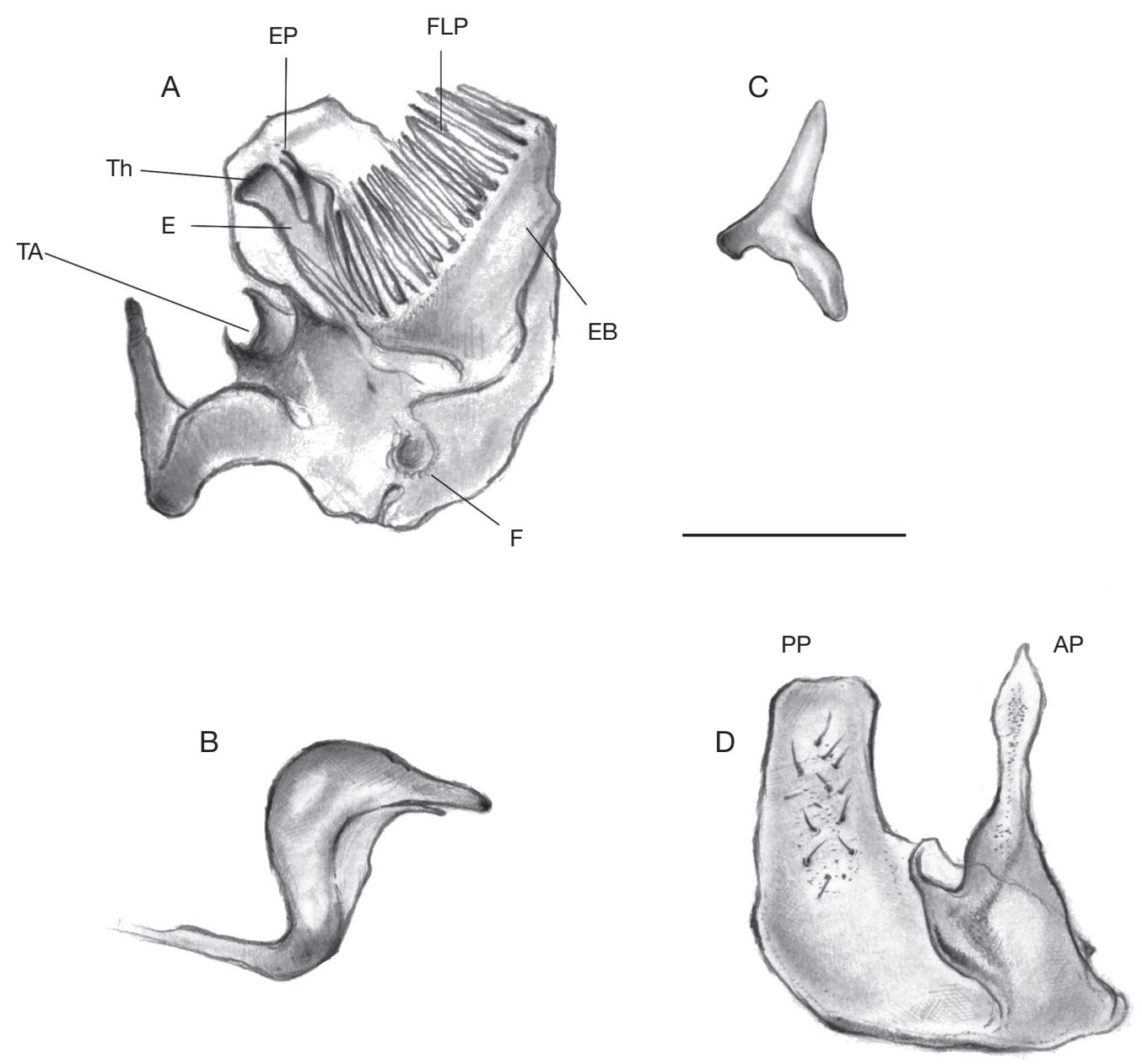

FIG. 7. - Piniphantes agnellus (Maurer \& Thaler, 1988) n. comb. (Linyphiidae): male from Valdieri (Italy): A, embolic division, dorsal view; B, lamella characteristica; C, Distal Suprategular apophysis; D, paracymbium. Abbreviations: AP, Apical Part of the paracymbium; E, Embolus; EB, Embolus Base; EP, Embolus Proper; F, Fickert's gland; FLP, Finger-Like Protrusions; L, Lamella characteristica; PP, Proximal Part of the paracymbium; TA, Terminal Apophysis; Th, Thumb. Scale bar: $0.04 \mathrm{~mm}$. Illustration by Stefano Mammola.

not elevated with a few bristles interspersed among the eyes. Clypeus 0.04 long, slightly indented under the eyes, then convex, with one bristle just below the head region. Eyes normally developed, with pigment and black margins. AME smallest. PLE, PME and ALE almost equal in diameter. ALE and PLE contiguous. PLE-PME distance: 0.011, ALE-AME distance: 0.012, PME-PME distance: 0.013. Eye diameters: AME: 0.015, PME: 0.020, ALE: 0.021, PLE: 0.210. Sternum heart-shaped, yellowish with blackish shades. Chelicerae 0.10 long, light brownish, with 18-20 lateral stridulatory ridges and armed with four contiguous posterior teeth grouped close to the base of the fang (the distal bigger) and three anterior teeth, equally distributed along the cheliceral margin, the median bigger. Legs uniformly light yellowish. Leg I: femur 0.56, other articles missing; leg II: femur 0.39, patella 0.09, tibia 0.65 , metatarsus 0.42 , tarsus 0.36 , TLL 1.91; leg III: femur 1.84 , patella 0.11 , other articles missing; leg IV: femur 0.48 , patella 0.12 , other articles missing. Abdomen 0.54 long, 0.38 wide; light-brownish, darker than the prosoma. Palp
(Fig. 6): femur 0.12, patella 0.04, tibia 0.03, cymbium 0.12 . Cymbium faintly convex, roughly rectangular when seen from above, ending proximally with a straight border, perpendicular to the main axis (Fig. 6B). Paracymbium U-shaped in lateral view, bearing some hairs on the proximal part, apical part gradually narrowed anteriorly (Figs 6A, 7D). Distal suprategular apophysis directed upwards, with a sharp end (Fig. 7C). Proximal part of the embolus with elongated projection bearing numerous finger-like protrusions (Fig. 7A). Embolus sickle shaped, thumb well-developed. Embolus proper bifid (Fig. 7A). Lamella characteristica duck-head shaped with an upper sclerotized horizontal branch and a lower one, smaller and less sclerotized (Fig. 7B).

\section{SPINATION (BASED ON ALL MALES EXAMINED)}

Femur I with one prolateral spine; femur II, III and IV with no spines. Patella I-IV with one dorsal spine. Tibia I with two dorsal, one prolateral, and one retrolateral spines; tibia II with one dorsal, and one prolateral and one retrolateral spines; 
A

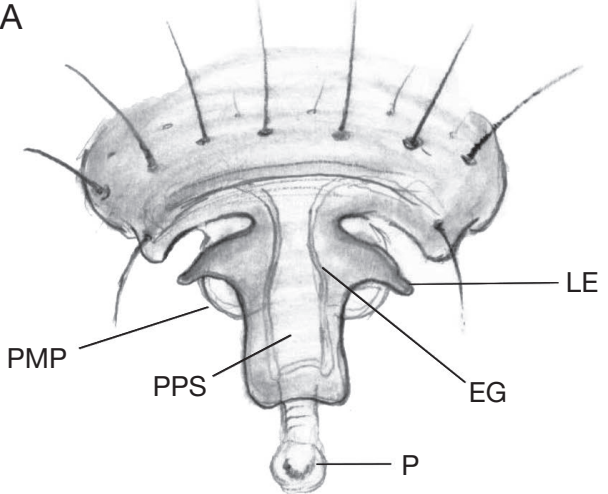

St
B

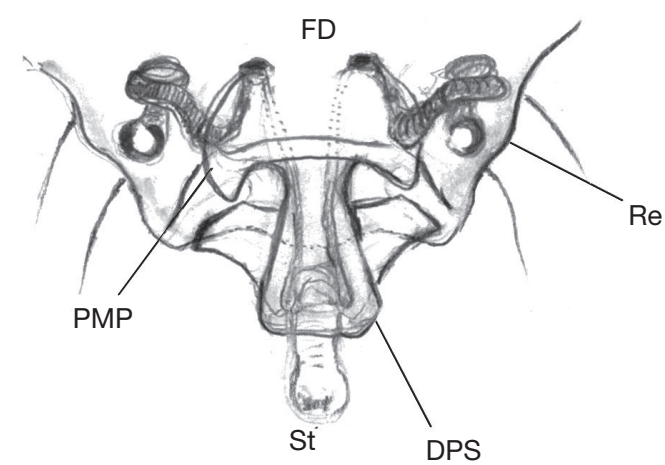

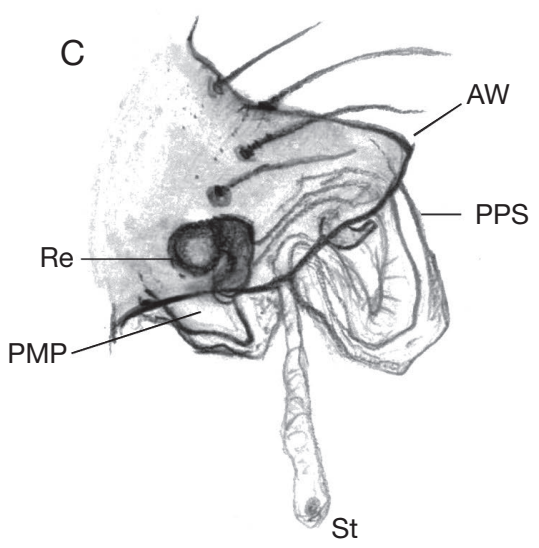

FIG. 8. - Piniphantes agnellus (Maurer \& Thaler, 1988) n. comb. (Linyphiidae): female from Barcelonnette (France): A, epigyne, ventral view; B, epigyne, dorsal view; C, epigyne, lateral view. Abbreviations: AW, Anterior Wall; DPS, Distal Part of the Scape; EG, Epigyinal Groves; FD, Fertilization Ducts; LE, Lateral Extension of the proscape; P, Pit; PMP, Posterior Median Plate; PPS, Proximal Part of the Scape (proscape); RE, Receptacula; St, Stretcher. Scale bar: 0.06 mm. Illustration by Stefano Mammola.

tibia III and IV with one dorsal and one retrolateral spines. Metatarsus I-IV with one dorsal spine. Position of TmI: 0.19. Trichobothrium on Mt IV absent.

\section{ECOLOGY AND DISTRIBUTION}

Specimens of $P$. agnellus $\mathrm{n}$. comb. have been collected primarily in talus caves and rocky areas at medium-high altitudes, between 1900 and $2600 \mathrm{~m}$ a.s.l. Mammola et al. (2018) consider the species as a troglophile elements. The distribution of the species is centred on the Alpine districts of Maritime Alps and Ligurian Alps. However, the record of one male in Champlas Janvier (Cottian Alps) let envisage a wider distribution, extending north.

\section{TAXONOMICAL REMARKS}

In the original description, Maurer \& Thaler (1988) assigned the newly described species to the genus Lepthyphantes Menge, 1866. In lack of males, the diagnosis - and presumably the genus assignation - was based on the morphology of the epigyne, bearing some characteristic lateral extensions at the base of the proscape. The occurrence of males of a possible undescribed species together with females of former Lephtyphantes agnellus at two sites (Galleria Valscura, Valdieri, Maritime Alps and Monte Grai, Triora, Ligurian Alps) allowed to pair males and females. Moreover, the match was confirmed by morphological characters shared by males and females, such as chaetotaxy, cheliceral teeth, stridulatory ridges, abdominal pattern and ocular pattern.

Some years after the description of L. agnellus, Saaristo \& Tanasevitch $(1993,1996)$ reclassified the genus Lepthyphantes using a typological approach, examining the morphology of the genital organs, especially males. As a result, most of the European Lepthyphantes species were transferred or assigned to new genera. On the other hand, given the lack of males, $L$. agnellus was not transferred to any of the newly created genera.

Our finding of the unknown male now allows the placement of this species within the genus Piniphantes Saaristo \& Tanasevitch, 1996. According to the original description, the genus Piniphantes includes small Linyphiids, having in males an elongated projection at the proximal part of the embolus 
bearing numerous finger-like protrusion (Saaristo \& Tanasevitch 1996). Such character is particularly remarkable in our case (Fig. 7A). Moreover, other details given in the genus description (Saaristo \& Tanasevitch 1996) match our case, such as chaetotaxy and lack of abdominal pattern.

The species is then assigned to the genus Piniphantes, with representatives in the area of Tian Shian Mountains (Central Asia) (5 species: P. cinereus (Tanasevitch, 1986), P. macer (Tanasevitch, 1986), P. plumatus (Tanasevitch, 1986), P. uzbekistanicus (Tanasevitch, 1983), P. zonsteini (Tanasevitch, 1989)), Himalaya (one species, P. himalayensis (Tanasevitch, 1987)), Centro-Asiatic-European region (one species, P.pinicola (Simon, 1884)) and Corsica (one species, P. cirratus (Thaler, 1986)). According to the morphology of the male genitalia, P. agnellus n. comb. is similar to P. cirratus, for which the only holotype male is known, preventing any comparison of the female.

\section{Pocadicnemis juncea Locket \& Millidge, 1953}

MATERIAL. — La Salce, wet grasslands, 1514 m, 01.VII.2017, Isaia, Mammola \& Milano leg., 2 \%, coll. MI.

Chorotype. - ASE.

MACROHABITAT. - Wet grasslands.

NOTE. - This species occurs mostly in open areas, preferring humid conditions (Nentwig et al. 2018).

\section{Tenuiphantes cristatus (Menge, 1866)}

MATERIAL. - La Salce, wet grasslands, 1514 m, 01.VII.2017, Isaia, Mammola \& Milano leg., 1 \%, coll. MI.

CHOROTYPe. — SIE.

MACROHABITAT. - Wet grasslands.

\section{Turinyphia clairi (Simon, 1884)}

Material. - Pathway to Chapeau de Gendarme, talus caves, $2047 \mathrm{~m}$, 02.VII.2017, Isaia \& Mammola leg., 1 \&, 1 ơ, 1 juv., coll. MI.

Chorotype. - WEU.

MacrohabitaT. - Caves.

NoTE. - Troglophile species according to Mammola et al. (2018), primarily inhabiting cave entrances and artificial subterranean habitats such as military bunkers. Apart from subterranean habitats, the species is also found in beech forests and shaded habitats (Isaia et al. 2017). Its presence outside French and Italian Maritime Alps (i.e., in Portugal) is regarded as doubtful by Pantini \& Isaia (2018).

\section{Walckenaeria antica (Wider, 1834)}

Material. - La Salce, mixed forest of Populus and Pinus, 1406 m, 01.VII.2017, Isaia, Mammola \& Milano leg., 1 \%, coll. MI.

CHorotype. - ASE.
MACROHABITAT. - Mixed forests.

Note. - Thermophilic species according to Nentwig et al. (2018).

Family LyCOSIDAE Sundevall, 1833

Alopecosa farinosa (Herman, 1879)

Material. - Chapeau de Gendarme, rocky lands, $2661 \mathrm{~m}$, 02.VII.2017, Isaia \& Mammola leg., 2 o", coll. MI.

CHOROTYPe. — SIE.

MACROHABITAT. - Rocky lands.

NoTE. - The nomenclature status of this species has been recently discussed in Breitling et al. (2016).

\section{Alopecosa alpicola (Simon, 1876)}

MATERIAL. — La Méa, rocky lands with snow, 2532 m, 02.VII.2017, Isaia \& Mammola leg., 2 \%, coll. MI.

Chorotype. - PAL.

MacrohabitaT. - Rocky lands.

NoTE. - This species is commonly found in alpine habitats above $2000 \mathrm{~m}$ a.s.l. (Lugetti \& Tongiorgi 1969).

\section{Aulonia albimana (Walckenaer, 1805)}

MATERIAL. - La Salce, wet grasslands, 1514 m, 01.VII.2017, Isaia, Mammola \& Milano leg., 1 ㅇ, coll. MI; Chemin de Gaudissard, stream, 1230 m, 01.VII.2017, Isaia, Mammola \& Milano leg., 1 \%, coll. MI; Les Allemands, ruderal areas, 1400 m, 01.VII.2017, Rollard leg., 1 \%, MNHN.

Chorotype. - EUR.

MACROHABITAT. - Wet grasslands, riparian habitats, ruderal areas.

\section{Pardosa agricola (Thorell, 1856)}

Material. - Ubaye river, river banks, 1120 m, 02.VII.2017, Milano leg., 2 ㅇ, $20^{\circ}$, coll. MI.

CHOrotype. - EUR.

MACROHABITAT. - Riparian habitats.

Note. - Females are hardly distinguishable from females of $P$. agrestis (Westring, 1861). However, the collection of a male in association with females made the identification of the species possible. Frequently found in humid areas and swampy regions (Nentwig et al. 2018).

\section{Pardosa alacris (C. L. Koch, 1833)}

MATERIAL. - La Salce, wet grasslands, 1514 m, 01.VII.2017, Isaia, Mammola \& Milano leg., 2 \%, $10^{\prime \prime}$, coll. MI.

Chorotype. - EUR. 
MACROHABITAT. — Wet grasslands.

NOTE. - The identification of specimens of the lugubris group based on morphological characters is hardly feasible. However, the collection of a male in association with females made the identification of the species possible. See also notes about Pardosa lugubris group.

\section{Pardosa amentata (Clerck, 1757)}

MATERIAL. — Ravin de Alaris, alpine prairies, 1980 m, 02.VII.2017, Isaia \& Mammola leg., 4 ㅇ, 1 ơ $^{7}$ coll. MI.

CHOROTYPe. - SIE.

MACROHABITAT. - Alpine prairies.

Pardosa bifasciata (C. L. Koch, 1834)

Material. - Salce basse, grass with low vegetation, $1225 \mathrm{~m}$, 01.VII.2017, Isaia, Mammola \& Milano leg., 1 ㅇ, coll. MI.

Chorotype. - PAL.

MACROHABITAT. — Shrublands.

\section{Pardosa blanda (C. L. Koch, 1833)}

MATERIAL. - Col Alaris, alpine pastures, 1724 m, 01.VII.2017, Isaia, Mammola \& Milano leg., 1 \%, coll. MI; Chapeau de Gendarme, rocky lands, $2661 \mathrm{~m}, 02$.VII.2017, Isaia \& Mammola leg., 4 ㅇ, 1 o", coll. MI; La Méa, rocky lands with snow, $2532 \mathrm{~m}$, 02.VII.2017, Isaia \& Mammola leg., $10^{7}$, coll. MI; Ravin de Alaris, alpine prairies, 1980 m, 02.VII.2017, Isaia \& Mammola leg., 1 ๆ, 1 ơ, MNHN.

Chorotype. - SEU.

MACROHABITAT. - Alpine pastures, rocky lands, alpine prairies.

\section{Pardosa hortensis (Thorell, 1872)}

MATERIAL. — Les Allemands, ruderal areas, 1400 m, 01.VII.2017, Rollard leg., 1 \%, MNHN; Salce basse, grass with low vegetation, 1225 m, 01.VII.2017, Isaia, Mammola \& Milano leg., 1 \&, coll. MI; Penelle, wet grasslands, 1277 m, 02.VII.2017, Rollard leg., 1 \% , MNHN; Ubaye river, river banks, 1120 m, 02.VII.2017, Milano leg., $10^{\prime \prime}$, coll. MI.

Chorotype. - PAL.

MACROHABitAT. - Ruderal areas, shrublands, wet grasslands, riparian habitats.

\section{Pardosa lugubris group}

Material. - Chemin de Gaudissard, stream, 1230 m, 01.VII.2017, Isaia, Mammola \& Milano leg., 2 \%, coll. MI; La Salce, mixed forest of Populus and Pinus, 1406 m, 01.VII.2017, Isaia, Mammola \& Milano leg., 1 \& , coll. MI; Peiroulier, broadleaved forests, $1357 \mathrm{~m}$, 01.VII.2017, Isaia, Mammola \& Milano leg., 3 ㅇ, coll. MI.

MACROHABITAT. — Riparian habitats, mixed forests, broadleaved forests.
Note. - The identification of species within the lugubris group based on morphological characters is hardly feasible. In particular, even with a certain degree of uncertainty due to potential species co-occurrence, females can only be identified when collected in association with male. Nevertheless, the species of this group are reproductively isolated, so the only reliable means of separating them at present is their courtship behaviour (Nentwig et al. 2018).

\section{Pardosa mixta (Kulczyński, 1887)}

MATERIAL. — La Méa, rocky lands with snow, 2532 m, 02.VII.2017, Isaia \& Mammola leg., 1 o", coll. MI.

Chorotype. - TUE.

MacrohabitaT. - Rocky lands.

\section{Pardosa monticola (Clerck, 1757)}

MATERIAL. - Les Amoz, grasslands with bushes, 1177 m, 30.VI.2017, Rollard leg., 1 \%, MNHN.

Chorotype. - PAL.

MACROHABITAT. — Shrublands.

\section{Pardosa nigra (C. L. Koch, 1834)}

Material. - Chapeau de Gendarme, rocky lands, $2661 \mathrm{~m}$, 02.VII.2017, Isaia \& Mammola leg., 3 ơ, coll. MI; La Méa, rocky lands with snow, 2532 m, 02.VII.2017, Isaia \& Mammola leg., $20^{\prime \prime}$, coll. MI.

CHOrotype. - EUR.

MACROHABITAT. — Rocky lands.

Note. - This species occurs frequently in alpine screes at higher altitudes.

\section{Pardosa paludicola (Clerck, 1757)}

Material. — Penelle, wet grasslands, 1277 m, 02.VII.2017, Rollard leg., 1 ㅇ, MNHN.

CHOROTYPE. - PAL.

MACROHABITAT. — Wet grasslands.

Note. - Hygrophilic species, preferentially found in dump areas (Nentwig et al. 2018).

\section{Pardosa palustris (Linnaeus, 1758)}

MATERIAL. — La Gravette, grasslands, 1130 m, 03.VII.2017, Isaia, Mammola \& Milano leg., 3 \%, $10^{7}$, coll. MI.

Chorotype. - OLA.

MACROHABITAT. - Alpine grasslands. 
Pardosa prativaga (L. Koch, 1870)

Material. — Penelle, wet grasslands, 1277 m, 02.VII.2017, Rollard leg., 1 \%, MNHN.

CHOROTYPE. — SIE.

MACrohabitAT. - Wet grasslands.

\section{Pardosa pullata (Clerck, 1757)}

Material. — Penelle, wet grasslands, 1277 m, 02.VII.2017, Rollard leg., 2 \%, MNHN.

CHOROTYPE. - SIE.

Macrohabitat. - Wet grasslands.

Pardosa wagleri (Hahn, 1822)

(Fig. 9)

Material. - Ubaye river, dry riverbed with pebbles, $1146 \mathrm{~m}$, 30.VI.2017, Isaia, Mammola \& Milano leg., 3,+ 4 ơ, coll. MI; Ubaye river, river banks, 1120 m, 02.VII.2017, Milano leg., 1 ơ, coll. MI.

Chorotype. - PAL.

MACROHABITAT. - Riparian habitats.

NoTE. - This species is frequently associated to riverbeds and dump areas, up to $1400 \mathrm{~m}$ a.s.l. (Nentwig et al. 2018).

\section{Pirata piraticus (Clerck, 1757)}

MAterial. - Penelle, wet grasslands, 1277 m, 02.VII.2017, Rollard leg., 1 \%, MNHN.

Chorotype. - OLA.

MACROHABITAT. - Wet grasslands.

NotE. - Hygrophilic species, frequently found near water.

\section{Trochosa hispanica Simon, 1870}

Material. - Salce basse, grass with low vegetation, $1225 \mathrm{~m}$, 01.VII.2017, Isaia, Mammola \& Milano leg., 1 \%, coll. MI.

Chorotype. - TUM.

MACROHABITAT. — Shrublands.

\section{Vesubia jugorum (Simon, 1881)}

(Fig. 10)

Material. - Chapeau de Gendarme, rocky lands, $2661 \mathrm{~m}$, 02.VII.2017, Isaia \& Mammola leg., 1 \%, 1 juv., coll. MI.

Chorotype. - ALSW.

MACROHABITAT. — Rocky lands.

Note. - High alpine endemic species of the South-Western Alps. This data represents one of westernmost locality of the species distribution. See the discussion for remarks on this finding.
Xerolycosa nemoralis (Westring, 1861)

MAterial. — La Salce, xeric grasslands, 1535 m, 01.VII.2017,

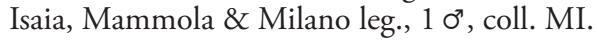

Chorotype. — PAL.

MACROHABITAT. - Alpine grasslands.

Family Mimetidae Simon, 1881

Ero aphana (Walckenaer, 1802)

MateriAl. - Les Amoz, low vegetation, 1212 m, 01.VII.2017, Isaia, Mammola \& Milano leg., 1 \%, coll. MI.

Chorotype. - EUR.

MACROHABITAT. - Shrublands.

Note. - Araneophagic species (Roberts 1995).

\section{Ero furcata (Villers, 1789)}

MATERIAL. — Peiroulier, broadleaved forests, 1357 m, 01.VII.2017, Isaia, Mammola \& Milano leg., 1 \%, coll. MI.

Chorotype. - PAL.

MACROHABITAT. — Broadleaved forests.

Note. - Araneophagic species (Roberts 1995).

Family MitURGIDAE Simon, 1886

Zora spinimana (Sundevall, 1833)

MATERIAL. - Les Allemands, ruderal areas, 1400 m, 01.VII.2017, Rollard leg., 1 \%, MNHN.

CHORotype. - PAL.

MACROHABITAT. — Ruderal areas.

Family OXYOPIDAE Thorell, 1870

Oxyopes heterophthalmus (Latreille, 1804)

MATERIAL. — Les Allemands, ruderal areas, 1400 m, 01.VII.2017, Rollard leg., 1 \%, MNHN.

Chorotype. - PAL.

MACROHABITAT. — Ruderal areas.

\section{Oxyopes lineatus Latreille, 1806}

Material. - La Salce, mixed forest of Populus and Pinus, $1406 \mathrm{~m}$, 01.VII.2017, Isaia, Mammola \& Milano leg., 1 ㅇ, coll. MI; Salce basse, xeric grasslands, $1255 \mathrm{~m}, 01$. VII.2017, Isaia, Mammola \& Milano leg., 1 \&, MNHN; Ubaye river, river banks, $1120 \mathrm{~m}$, 02.VII.2017, Milano leg., 2 \%, 3 o", coll. MI.

CHOrotype. - TUE.

MACROHABITAT. - Mixed forests, alpine grasslands, riparian habitats. 


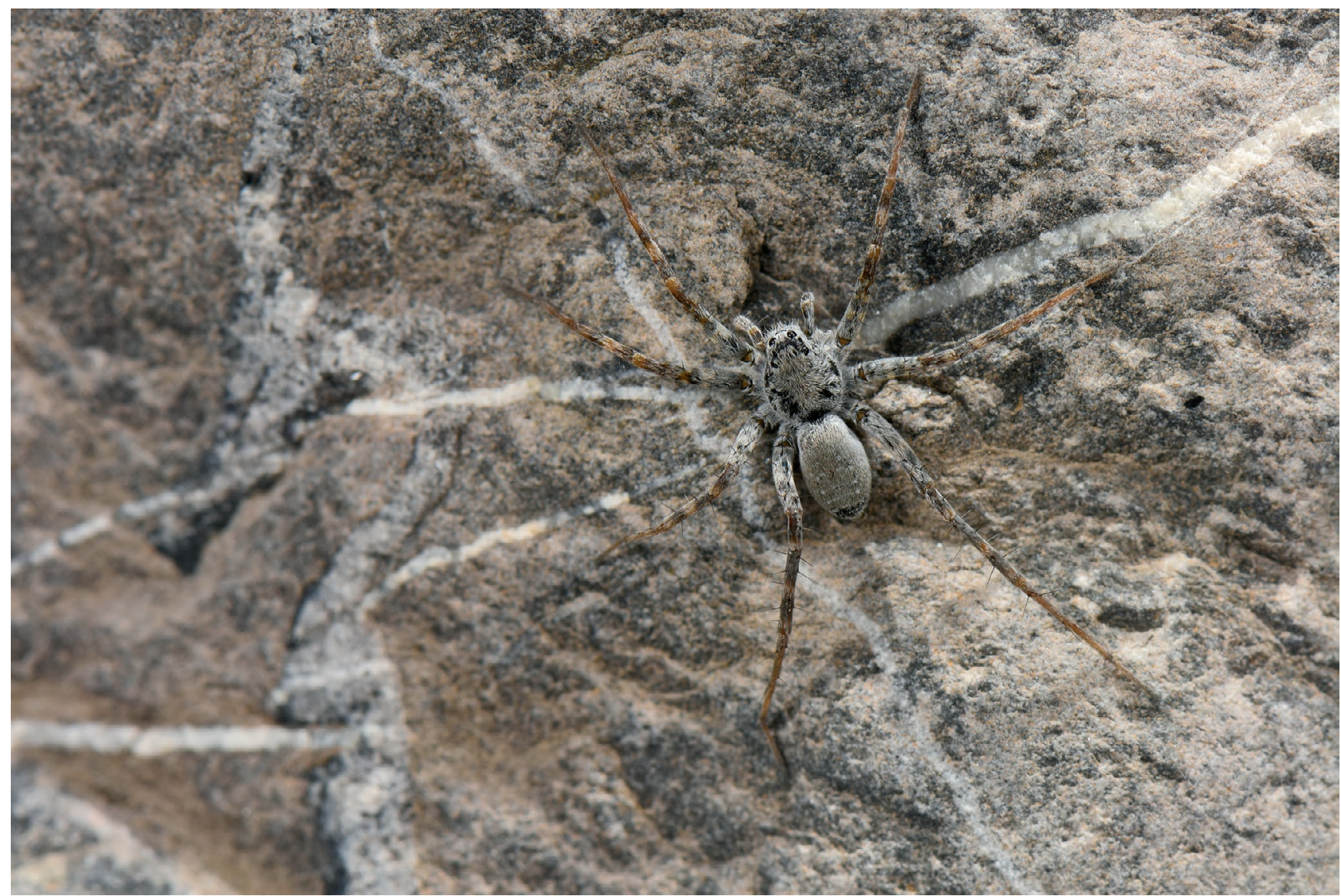

FIG. 9. - Pardosa wagleri (Hahn, 1822) (Lycosidae). Average body length of the female: 6-8.2 mm. Photo credit: Francesco Tomasinelli, Parc national du Mercantour.

Family PHILODROMIDAE Thorell, 1870

\section{Philodromus aureolus (Clerck, 1757)}

MATERIAL. —Chemin de Gaudissard, stream, 1230 m, 01.VII.2017, Isaia, Mammola \& Milano leg., 1 \%, coll. MI.

CHOROTYPE. - PAL.

MACROHABITAT. — Riparian habitats.

\section{Philodromus cespitum (Walckenaer, 1802)}

MATERial. - Penelle, wet grasslands, 1277 m, 02.VII.2017, Rollard leg., 1 \%, MNHN; Salce basse, grass with low vegetation, $1225 \mathrm{~m}$, 01.VII.2017, Isaia, Mammola \& Milano leg., 1 \% , coll. MI.

Chorotype. - OLA.

MACROHABitaT. - Wet grasslands, shrublands.

\section{Philodromus emarginatus (Schrank, 1803)}

MATERIAL. - Ubaye river, river banks, 1120 m, 02.VII.2017, Milano leg., 1 ㅇ, coll. MI.

Chorotype. - PAL.

MACROHABITAT. - Riparian habitats.
Philodromus fuscolimbatus Lucas, 1846

MATERIAL. — Les Allemands, ruderal areas, 1455 m, 01.VII.2017, Rollard leg., 1 o", MNHN.

Chorotype. - MED.

Macrohabitat. - Ruderal areas.

\section{Philodromus vagulus Simon, 1875}

MATERIAL. — Ravin de Alaris, alpine prairies, 1980 m, 02.VII.2017, Isaia \& Mammola leg., 1 \%, coll. MI.

Chorotype. - EUR.

MACROHABITAT. - Alpine prairies.

Note. - Rare, biology mostly unknown (Nentwig et al. 2018).

\section{Thanatus atratus Simon, 1875}

MATERIAL. - Salce basse, grass with low vegetation, $1225 \mathrm{~m}$, 01.VII.2017, Isaia, Mammola \& Milano leg., 1 ơ, coll. MI.

Chorotype. - PAL.

MACrOHABITAT. — Shrublands. 
Tibellus oblongus (Walckenaer, 1802)

Material. - Salce basse, xeric grasslands, 1255 m, 01.VII.2017, Isaia, Mammola \& Milano leg., 1 \%, coll. MI.

Chorotype. - OLA.

MACROHABITAT. - Alpine grasslands.

Family PHOLCIDAE C. L. Koch, 1850

Pholcus phalangioides (Fuesslin, 1775)

Material. - Séolane Center, on walls of buildings, $1152 \mathrm{~m}$, 01.VII.2017, Isaia, Mammola \& Milano leg., 1 ㅇ, MNHN.

Chorotype. - COS.

MacrohabitAT. - Urban habitats.

Family PHRUROLITHIDAE Banks, 1892

Phrurolithus festivus (C. L. Koch, 1835)

Material. - Bois de Gaudissart, Silver fir woods, $1414 \mathrm{~m}$, 01.VII.2017, Isaia, Mammola \& Milano leg., 1 \%, coll. MI.

Chorotype. - PAL.

MacrohabitaT. — Coniferous forests.

Note. - This species, as many other of the genus Phrurolithus C.L. Koch, 1839 is an ant mimic and is often found in association with ants.

Family PISAURIDAE Simon, 1890

Pisaura mirabilis (Clerck, 1757)

(Fig. 11)

MATERIAL. — La Salce, wet grasslands, 1514 m, 01.VII.2017, Isaia, Mammola \& Milano leg., 1 \%, MNHN; Les Allemands, ruderal areas, 1400 m, 01.VII.2017, Rollard leg., 3 juv., MNHN.

Chorotype. - ASE.

MACROHABITAT. — Wet grasslands, ruderal areas.

Family SALTICIDAE Blackwall, 1841

Aelurillus v-insignitus (Clerck, 1757)

Material. — La Méa, rocky lands with snow, 2532 m, 02.VII.2017, Isaia \& Mammola leg., 3 \%, coll. MI.

Chorotype. - PAL.

MACROHABITAT. - Rocky lands.
Attulus distinguendus (Simon, 1868)

Material. - Col Alaris, alpine pastures, 1724 m, 01.VII.2017, Isaia, Mammola \& Milano leg., 1 \%, coll. MI.

CHOROTYPe. — SIE.

MACROHABITAT. - Alpine pastures.

Euophrys frontalis (Walckenaer, 1802)

Material. - La Salce, mixed forest of Populus and Pinus, $1406 \mathrm{~m}$, 01.VII.2017, Isaia, Mammola \& Milano leg., 1 으, MNHN; Peiroulier, broadleaved forests, 1357 m, 01.VII.2017, Isaia, Mammola \& Milano leg., 1 \%, coll. MI.

Chorotype. - PAL.

MacrohabitaT. - Mixed forests, broadleaved forests.

\section{Evarcha arcuata (Clerck, 1757)}

MATERIAL. - La Salce, wet grasslands, 1514 m, 01.VII.2017, Isaia, Mammola \& Milano leg., 1 9 , $30^{7}$, MNHN; Penelle, wet grasslands, 1277 m, 02.VII.2017, Rollard leg., 4 ㅇ, 1 ơ, 1 juv., MNHN.

Chorotype. - PAL.

MACROHABITAT. - Wet grasslands.

Heliophanus lineiventris Simon, 1868

MATERIAL. — La Méa, rocky lands with snow, 2532 m, 02.VII.2017, Isaia \& Mammola leg., 1 Ơ $^{\prime}$, coll. MI.

Chorotype. - PAL.

MacrohabitaT. - Rocky lands.

Note. - This species occurs in dry locations up to $2600 \mathrm{~m}$ a.s.l. (Nentwig et al. 2018)

\section{Heliophanus kochii Simon, 1868}

MATERIAL. - Salce basse, xeric grasslands, 1255 m, 01.VII.2017, Isaia, Mammola \& Milano leg., 1 \%, coll. MI.

Chorotype. - EUM.

MACROHABITAT. - Alpine grasslands.

Heliophanus patagiatus Thorell, 1875

MATERIAL. - Ubaye river, dry riverbed with pebbles, $1146 \mathrm{~m}$, 30.VI.2017, Isaia, Mammola \& Milano leg., 3 \%, coll. MI.

Chorotype. — ASE.

MACROHABITAT. — Riparian habitats.

NoTE. - Rarely found, mostly on rocky borders of flowing waters (Nentwig et al. 2018). 


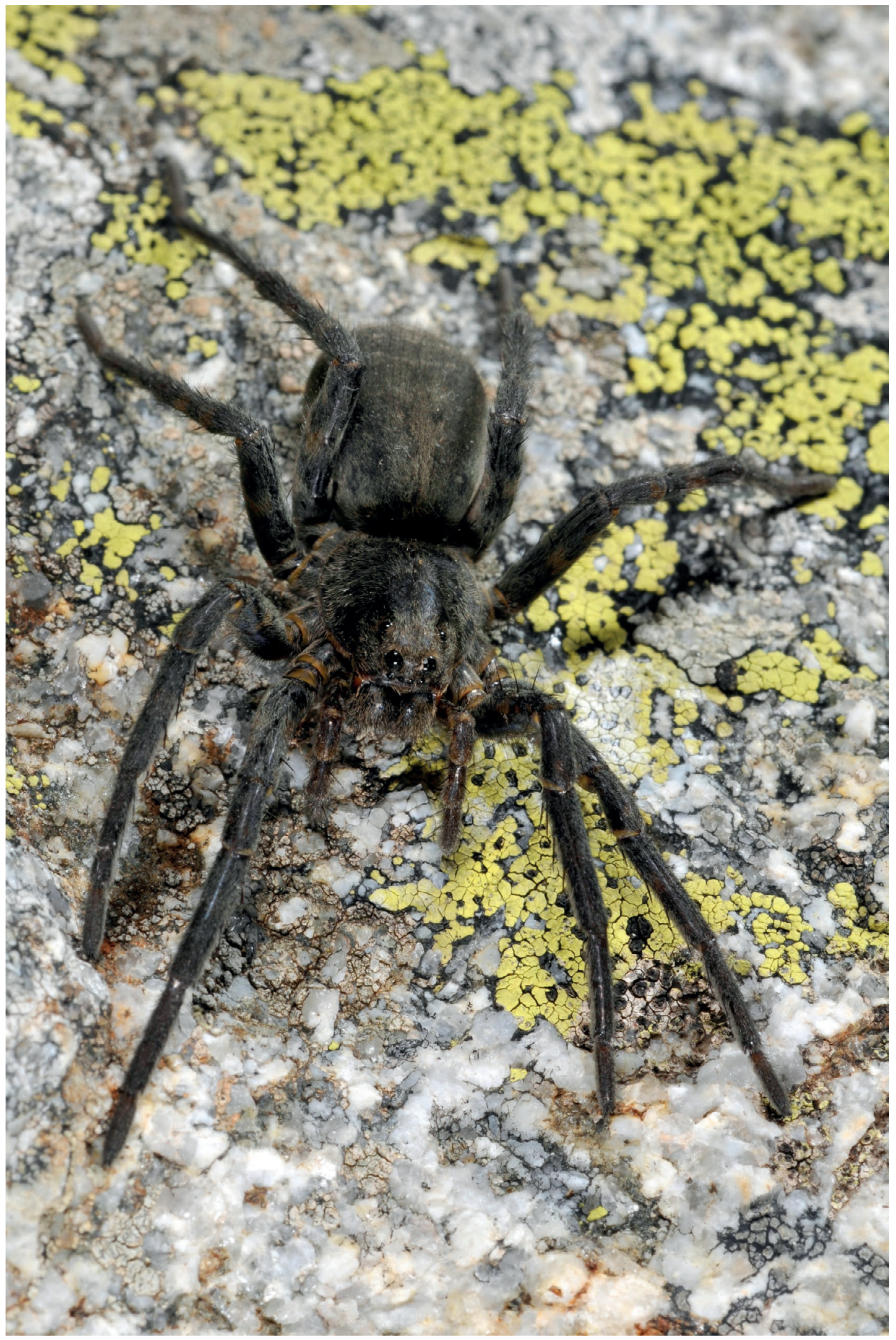

Fig. 10. - Vesubia jugorum (Simon, 1881) (Lycosidae). Average body length of the female: 15-20 mm. Photo credit: Francesco Tomasinelli, Parc national du Mercantour. 
Pellenes tripunctatus (Walckenaer, 1802)

MATERIAL. — Les Amoz, grasslands with bushes, 1177 m, 30.VI.2017, Rollard leg., 1 \%, MNHN.

Chorotype. - SIE.

MACROHABITAT. — Shrublands.

\section{Pseudeuophrys lanigera (Simon, 1871)}

MATERIAL. — La Méa, rocky lands with snow, 2532 m, 02.VII.2017, Isaia \& Mammola leg., 2 ơ, coll. MI.

CHOrotype. — EUR.

MACROHABITAT. - Rocky lands.

Family SEGESTRIIDAE Simon, 1893

$$
\text { Segestria senoculata (Linnaeus, 1758) }
$$

MATERIAL. - Salce basse, xeric grasslands, 1255 m, 01.VII.2017, Isaia, Mammola \& Milano leg., 1 juv., coll. MI.

CHOROTYPe. - PAL.

MACROHABITAT. - Alpine grasslands.

Family SPARASSIDAE Bertkau, 1872

Micrommata virescens (Clerck, 1757)

(Fig. 12)

MATERIAL. — La Salce, wet grasslands, 1514 m, 01.VII.2017, Isaia, Mammola \& Milano leg., 1 \&, coll. MI; Penelle, wet grasslands, 1277 m, 02.VII.2017, Rollard leg., 1 \&, MNHN.

Chorotype. - PAL.

MacrohaBitAT. - Wet grasslands.

Family Tetragnathidae Menge, 1866

Metellina merianae (Scopoli, 1763)

Material. - La Salce, mixed forest of Populus and Pinus, 1406 m, 01.VII.2017, Isaia, Mammola \& Milano leg., 1 ㅇ, coll. MI.

Chorotype. - EUR.

MacrohabitAT. — Mixed forests.

Tetragnatha extensa (Linnaeus, 1758)

MAterial. - Penelle, wet grasslands, 1277 m, 02.VII.2017, Rollard leg., 6 ㅇ, $20^{7}$, MNHN.

Chorotype. - OLA.

MACROHABITAT. - Wet grasslands.

NOTE. - On herbaceous plants in humid, open habitats, always near water (Nentwig et al. 2018).
Family THERIDIIDAE Sundevall, 1833

Chrysso nordica (Chamberlin \& Ivie, 1947)

MATERIAL. - Ubaye river, river banks, 1120 m, 02.VII.2017, Milano leg., 1 ơ, coll. MI.

Chorotype. - OLA.

MACROHABITAT. - Riparian habitats.

Note. - New record for France. The species is known for North America, Hungary, Ukraine to East Russia, Kazakhstan and Mongolia (Dondale et al. 1997; Marusik et al. 2000; Szinetár et al. 2002). The presence of this species in France seems plausibly related to anthropogenic introduction.

\section{Dipoena melanogaster (C. L. Koch, 1837)}

MATERIAL. — Les Amoz, grasslands with bushes, 1177 m, 30.VI.2017, Rollard leg., 1 juv., MNHN; Les Amoz, low vegetation, 1212 m, 01.VII.2017, Isaia, Mammola \& Milano leg., 3 9, MNHN; Peiroulier, broadleaved forests, $1357 \mathrm{~m}, 01$.VII.2017, Isaia, Mammola \& Milano leg., 1 ㅇ, coll. MI; Penelle, wet grasslands, 1277 m, 02.VII.2017, Rollard leg., 1 ㅇ, MNHN.

CHOROTYPe. — EUR.

MACROHABITAT. - Shrublands, broadleaved forests, wet grasslands.

\section{Dipoena torva (Thorell, 1875)}

MATERIAL. - Col Alaris, alpine pastures, 1724 m, 01.VII.2017, Isaia, Mammola \& Milano leg., $10^{7}$, coll. MI.

CHorotype. - OLA.

MACROHABITAT. - Alpine pastures.

Note. - This is a relatively rare species (Nentwig et al. 2018). It appears to be an arboreal species with a distinct habitat on pine and oak trunks, even though were found occasionally in the understorey (Simon 1997). D. torva is a specialist ant predator.

\section{Enoplognatha caricis (Fickert, 1876)}

Material. — La Salce, wet grasslands, 1514 m, 01.VII.2017, Isaia, Mammola \& Milano leg., 2 ㅇ, coll. MI.

Chorotype. - OLA.

MACROHABITAT. - Wet grasslands.

Note. - This species is generally associated to wetlands, namely bogs and swamp (Le Peru 2011; Nentwig et al. 2018).

\section{Enoplognatha latimana Hippa \& Oksala, 1982}

MATERIAL. — La Salce, wet grasslands, 1514 m, 01.VII.2017, Isaia, Mammola \& Milano leg., 1 ㅇ, 3 o", coll. MI.

Chorotype. — PAL.

MacrohabitaT. - Wet grasslands. 


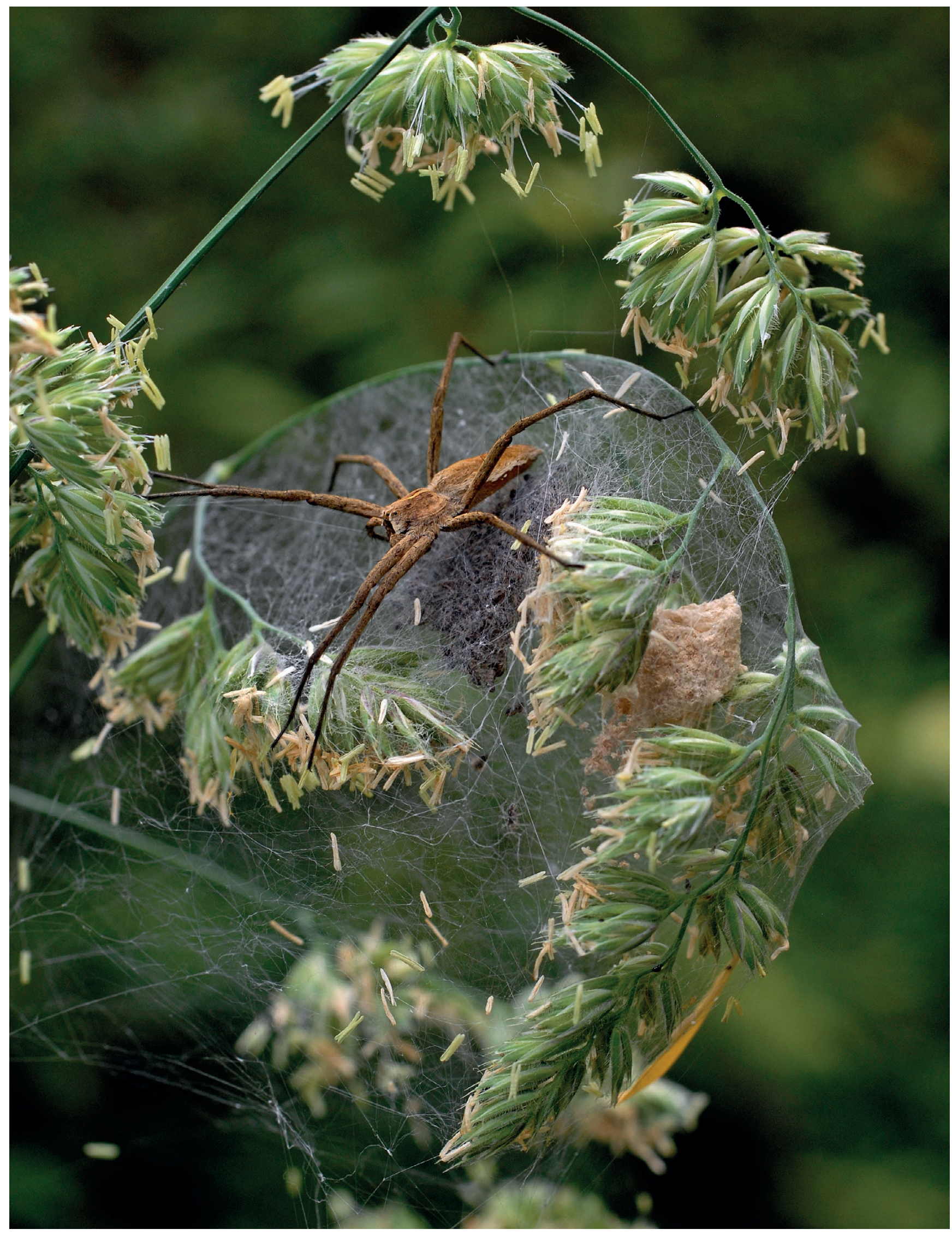

Fig. 11. - Pisaura mirabilis (Clerck, 1757) (Pisauridae). Average body length of the female: 12-15 mm. Photo credit: Francesco Tomasinelli, Parc national du Mercantour. 
Enoplognatha mandibularis (Lucas, 1846)

Material. - La Salce, mixed forest of Populus and Pinus, 1406 m, 01.VII.2017, Isaia, Mammola \& Milano leg., 1 \%, coll. MI.

Chorotype. - SIE.

MacrohabitaT. — Mixed forests.

\section{Enoplognatha ovata (Clerck, 1757)}

MATERIAL. - Chemin de Gaudissard, stream, 1230 m, 01.VII.2017, Isaia, Mammola \& Milano leg., 1 \%, $10^{\Uparrow}$, coll. MI; Les Allemands, ruderal areas, 1400 m, 01.VII.2017, Rollard leg., 2 \%, MNHN.

Chorotype. - OLA.

MACROHABITAT. - Riparian habitats, Ruderal areas.

\section{Episinus algiricus Lucas, 1846}

MATERIAL. — Les Amoz, low vegetation, 1212 m, 01.VII.2017, Isaia, Mammola \& Milano leg., $1 \%$, coll. MI.

CHOROTYPe. - WME.

MACROHABITAT. — Shrublands.

NoTE. - This species is apparently confined to the western Mediterranean (Knoflach et al. 2009).

\section{Heterotheridion nigrovariegatum (Simon, 1873)}

MATERIAL. - La Salce, xeric grasslands, 1535 m, 01.VII.2017, Isaia, Mammola \& Milano leg., 1 , coll. MI.

Chorotype. - PAL.

MACROHABitaT. - Alpine grasslands.

Note. - This species occurs in dry and semi-dry habitats (Le Peru 2011).

\section{Lasaeola tristis (Hahn, 1833)}

MATERIAL. — Les Allemands, ruderal areas, 1400 m, 01.VII.2017, Rollard leg., 1 ㅇ, MNHN.

Chorotype. - TUE.

MACROHABITAT. — Ruderal areas.

\section{Neottiura bimaculata (Linnaeus, 1767)}

MATERIAL. - La Salce, wet grasslands, 1514 m, 01.VII.2017, Isaia, Mammola \& Milano leg., 1 ơ $^{\pi}$, coll. MI.

Chorotype. - OLA.

MACROHABITAT. - Wet grasslands.

Note. - Nentwig et al. (2018) regard this species as hygrophilic.
Neottiura suaveolens (Simon, 1880)

MATERIAL. - La Salce, wet grasslands, 1514 m, 01.VII.2017, Isaia, Mammola \& Milano leg., 1 ㅇ, coll. MI.

CHOROTYPe. - EUR.

MACROHABITAT. - Wet grasslands.

Note. - According to Nentwig et al. (2018) this species occurs commonly in warm, dry meadows and in litter layer of warm habitats. However, Knoflach (1999) and Le Peru (2011) recorded this species also in wetlands.

\section{Parasteatoda lunata (Clerck, 1757)}

MATERIAL. — Les Amoz, grasslands with bushes, 1177 m, 30.VI.2017, Rollard leg., 1 juv., MNHN; Salce basse, grass with low vegetation, 1225 m, 01.VII.2017, Isaia, Mammola \& Milano leg., 1 \%, coll. MI; Séolane Center, on walls of buildings, $1152 \mathrm{~m}, 01$.VII.2017, Isaia, Mammola \& Milano leg., 1 ㅇ, $10^{\circ}$, MNHN.

Chorotype. - PAL.

MACROHABITAT. — Shrublands, Urban habitats.

Phylloneta impressa (L. Koch, 1881)

MATERiAL. - Les Allemands, ruderal areas, 1400 m, 01.VII.2017, Rollard leg., $20^{\prime \prime}, 1$ juv., MNHN; Salce basse, grass with low vegetation, 1225 m, 01.VII.2017, Isaia, Mammola \& Milano leg., 1 ㅇ, coll. MI; Séolane Center, on walls of buildings, $1152 \mathrm{~m}$, 01.VII.2017, Isaia, Mammola \& Milano leg., 1 \&, $10^{\prime \prime}$, coll. MI; Ubaye river, river banks, 1120 m, 02.VII.2017, Milano leg., $20^{*}$, MNHN.

Chorotype. - OLA.

MACROHABITAT. - Ruderal areas, shrublands, urban habitats, riparian habitats.

\section{Robertus truncorum (L. Koch, 1872)}

Material. - Col Alaris, alpine pastures, 1724 m, 01.VII.2017, Isaia, Mammola \& Milano leg., 1 \%, coll. MI.

Chorotype. - CEU.

MACROHABITAT. — Alpine pastures.

NotE. - Rarely found, this species occurs in subalpine region (Nentwig et al. 2018).

Theridion varians Hahn, 1833

MATERIAL. - La Salce, wet grasslands, 1514 m, 01.VII.2017, Isaia, Mammola \& Milano leg., 1 ㅇ, coll. MI.

Chorotype. - OLA.

Macrohabitat. — Wet grasslands. 


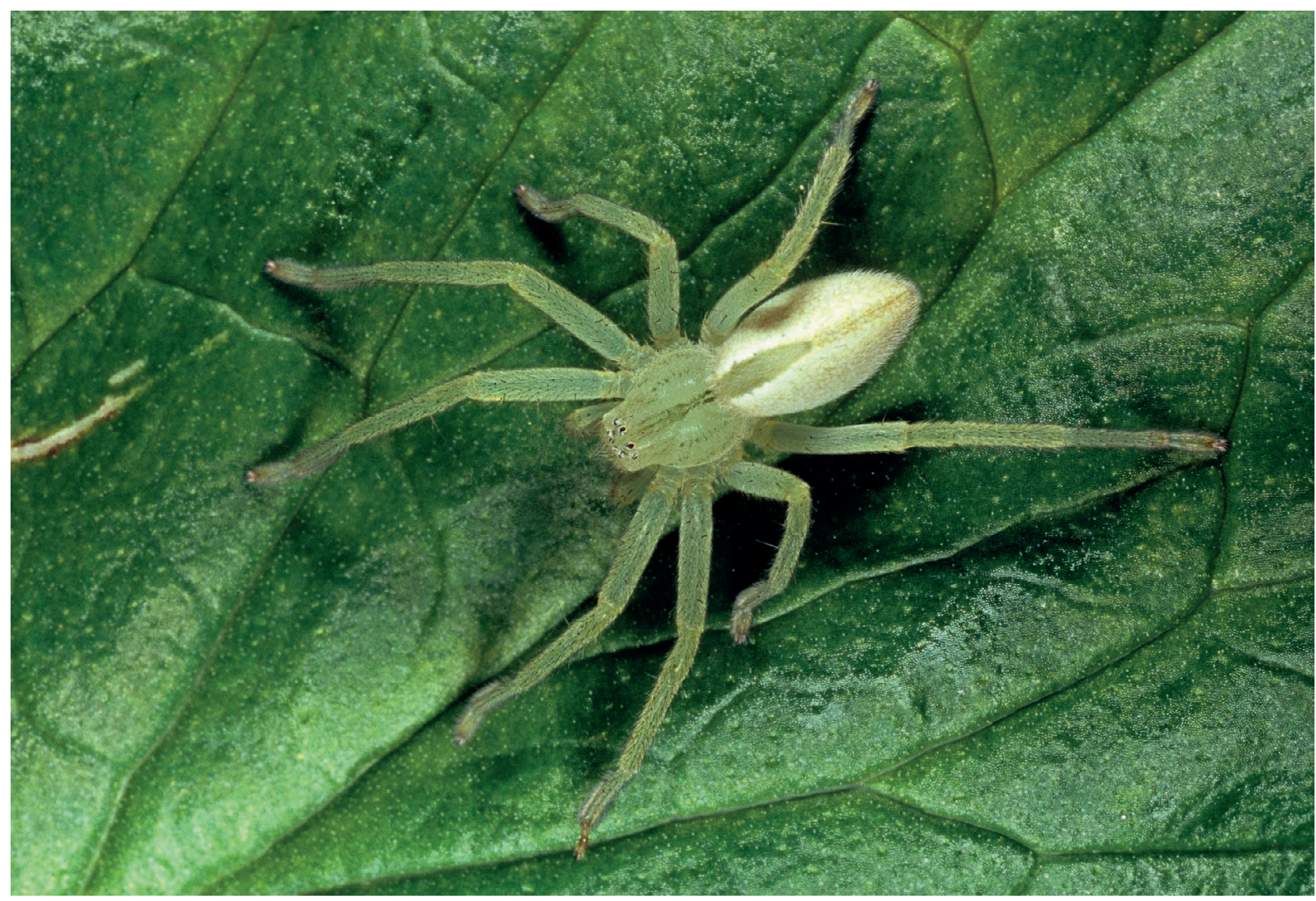

Fig. 12. - Micrommata virescens (Clerck, 1757) (Sparassidae). Average body length of the female: 12-16.6 mm. Photo credit: Francesco Tomasinelli, Parc national du Mercantour.

Family THOMISIDAE Sundevall, 1833

\section{Misumena vatia (Clerck, 1757)}

MATERIAL. — Les Amoz, grasslands with bushes, 1177 m, 30.VI.2017, Rollard leg., 1 juv., MNHN; La Salce, xeric grasslands, $1535 \mathrm{~m}$, 01.VII.2017, Isaia, Mammola \& Milano leg., 1 9, coll. MI; Les Allemands, ruderal areas, $1400 \mathrm{~m}, 01 . \mathrm{VII} .2017$, Rollard leg., $2 \circ$, MNHN; Penelle, wet grasslands, 1277 m, 02.VII.2017, Rollard leg., 1 juv., MNHN.

CHOROTYPe. - OLA.

MACROHABITAT. - Shrublands, alpine grasslands, ruderal areas, wet grasslands.

\section{Ozyptila praticola (C. L. Koch, 1837)}

MATERIAL. — Chemin de Gaudissard, stream, 1230 m, 01.VII.2017, Isaia, Mammola \& Milano leg., 1 \%, coll. MI.

CHOROTYPe. - OLA.

MACrohabitat. — Riparian habitats.

\section{Ozyptila rauda Simon, 1875}

MATerial. - Ubaye river, dry riverbed with pebbles, $1146 \mathrm{~m}$, 30.VI.2017, Isaia, Mammola \& Milano leg., 1 \%, coll. MI.

CHOROTYPE. — SIE.

MACROHABITAT. — Riparian habitats.

Note. - This species is rarely found (Nentwig et al. 2018).

\section{Synema globosum (Fabricius, 1775)}

Material. - La Salce, mixed forest of Populus and Pinus, $1406 \mathrm{~m}$, 01.VII.2017, Isaia, Mammola \& Milano leg., 1 , coll. MI.

CHOROTYPE. - PAL.

Macrohabitat. — Mixed forests.

\section{Thomisus onustus Walckenaer, 1805}

(Fig. 13)

MATERIAL. — Les Allemands, ruderal areas, 1455 m, 01.VII.2017, Rollard leg., 1 on $^{n}$ MNHN; Les Allemands, ruderal areas, $1400 \mathrm{~m}$, 01.VII.2017, Rollard leg., 1 9, $10^{\text {}}$, MNHN; Salce basse, grass with 


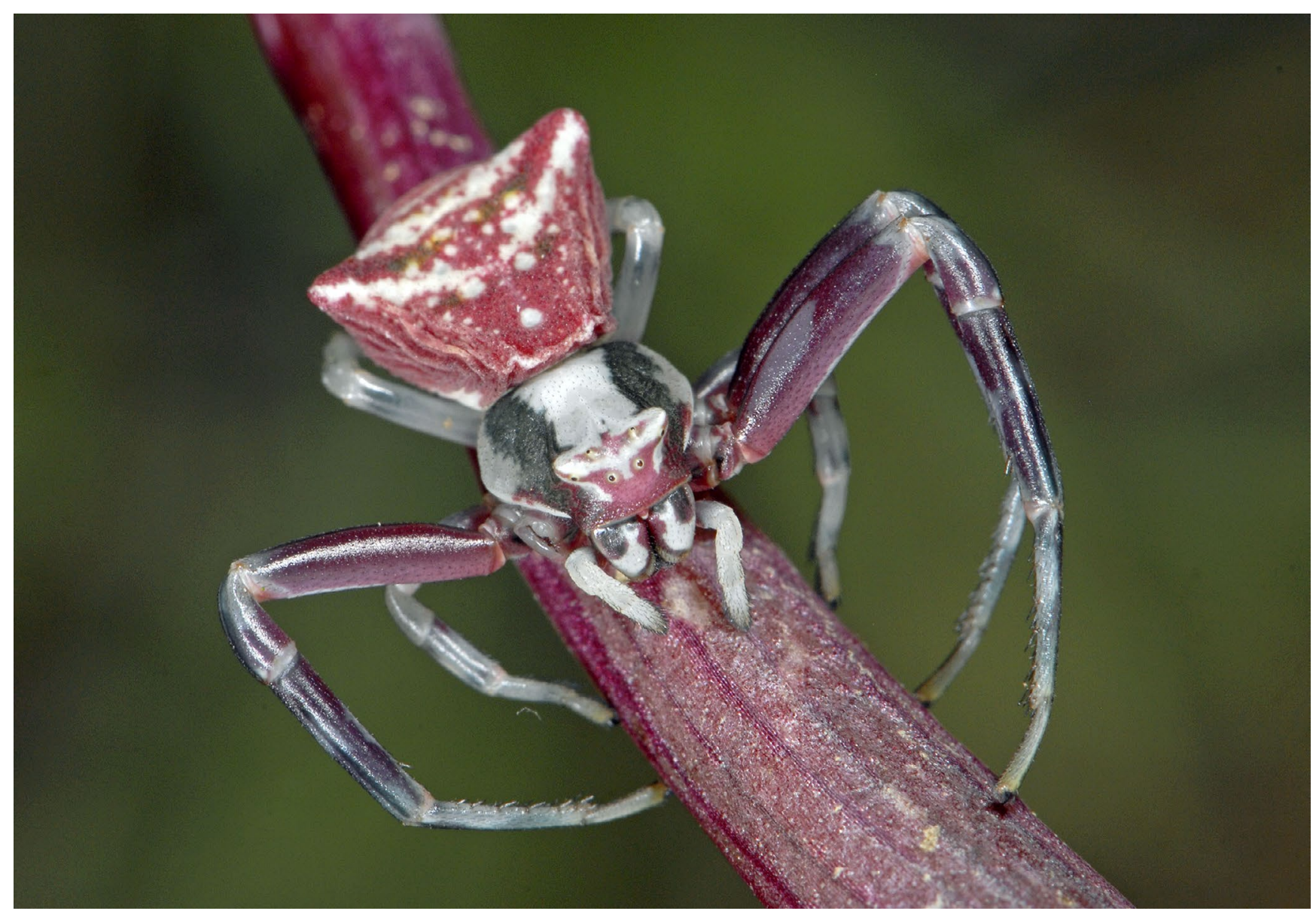

FIG. 13. - Thomisus onustus Walckenaer, 1805 (Thomisidae). Average body length of the female: 7-10 mm. Photo credit: Francesco Tomasinelli, Parc national du Mercantour.

low vegetation, $1225 \mathrm{~m}, 01$. VII.2017, Isaia, Mammola \& Milano leg., 1 juv., coll. MI.

Chorotype. - PAL.

MACROHABITAT. — Ruderal areas, shrublands.

\section{Xysticus cristatus (Clerck, 1757)}

Material. — Penelle, wet grasslands, 1277 m, 02.VII.2017, Rollard leg., 2 o", MNHN.

Chorotype. - PAL.

MacrohabitAT. - Wet grasslands.

\section{Xysticus kochi Thorell, 1872}

MATERIAL. - Salce basse, xeric grasslands, 1255 m, 01.VII.2017, Isaia, Mammola \& Milano leg., 1 ㅇ, coll. MI.

CHOROtYPe. — SIE.

Macrohabitat. - Alpine grasslands.

\section{Xysticus ninnii Thorell, 1872}

MATERIAL. — La Salce, wet grasslands, 1514 m, 01.VII.2017, Isaia, Mammola \& Milano leg., 1 \%, coll. MI; La Salce, xeric grasslands, 1535 m, 01.VII.2017, Isaia, Mammola \& Milano leg., $10^{7}$, coll. MI.

Chorotype. - SIE.

MACROHABITAT. - Wet grasslands, alpine grasslands.

Family UlobORIDAE Thorell, 1869

Hyptiotes paradoxus (C. L. Koch, 1834)

Material. - Les Amoz, low vegetation, 1212 m, 01.VII.2017, Isaia, Mammola \& Milano leg., 1 juv., coll. MI.

Chorotype. - PAL.

MACROHABITAT. — Shrublands.

NoTE. - This species is mostly reported from spruce forests, especially in low mountain ranges, where it builds webs on lower twigs of trees (Wiehle 1953). 


\section{DISCUSSION}

This work provides the first inventory of the spider species recorded in the municipality of Barcelonnette. So far, data on the local spider fauna are available only at regional level, for the Alpes-de-Haute-Provence Department, with 292 species specifically recorded within the Department (Simon 1874a, b, 1875a, b, c, 1876, 1878, 1879, 1881, 1882, 1884a, b, 1898, 1913, 1914, 1926, 1929, 1932, 1937; PickardCambridge 1875; Peyerimhoff 1906; Jeannel 1926; Dresco 1962, 1966, 1987; Luczack \& Vedovini 1964; Kraus \& Baur 1974; Dresco \& Hubert 1975; Brignoli 1978; Müller 1985; Wunderlich 1995; Bosmans 1997; Metzner 1999; Bosmans \& van Keer 1999; Le Peru 2007). This number raises up to 610 species when considering common species, distributed in the whole of France according to Simon (1914, $1926,1929,1932,1937)$. On the contrary, no specific data is available in literature for the Barcelonnette area, except for sporadic observations reported by Pickard-Cambridge (1875) and Simon (1926) from the area between Embrun and Barcelonnette. Simon (1926) reported the occurrence of Walckenaeria furcillata (Menge, 1869), while PickardCambridge (1875) recorded the presence of Araeoncus vaporariorum (O. Pickard-Cambridge, 1875) and Diplocephalus cristatus (Blackwall, 1833).

As the result of the sampling carried out during the "Explor'Nature" event, specimens belonging to 120 species, 83 genera and 25 families have been collected. The final species count also includes specimens of doubtful identification such as females of Pardosa lugubris group and Dysdera ninnii group.

In terms of species richness, the family Lycosidae dominates with 22 species (18\%), followed by Theridiidae (16 species, 13\%) and Linyphiidae (13 species, 11\%). See Fig. 14 for further details. Twenty-six species are recorded for the first time in the Alpes-de-Haute-Provence Department, raising the total number of species known for this Department to 318 (Table 3).

Two species (Chrysso nordica (Chamberlin \& Ivie, 1947) and Urozelotes trifidus Tuneva, 2003 are recorded for the first time in France. Chrysso nordica, is a theridiid with Holarctic distribution. It was found in North America, from Alaska to the Northwest Territories south to California and Colorado in the Nearctic (Dondale et al. 1997), while its Palearctic range embeds Ukraine, Hungary, South Ural throughout South Siberia to the Magadan Area, Mongolia and China (Marusik et al. 2000). This species is characteristic of the steppes, dry meadows and dry saline areas, and was reported in dry, acidic sandy grasslands (Charitonov 1950; Azheganova 1968; Marusik et al. 2000; Szinetár et al. 2002). This species was elsewhere reported in very disturbed sites (Szinetár et al. 2002), an observation that supports the hypothesis of an anthropogenic introduction in France. In our case, the species was collected in riparian habitats, alongside the Ubaye riverbed, attesting the role of these habitats as potential source of introduction of alien species. Riparian habitats are considered to be particularly
TABLE 3. - List of new records for the Alpes-de-Haute-Provence Department. Bold species are new for France.

\begin{tabular}{ll}
\hline Family & Species \\
\hline Dictynidae & Dictyna pusilla Thorell, 1856 \\
Gnaphosidae & Gnaphosa nigerrima L. Koch, 1877 \\
& Micaria formicaria (Sundevall, 1831) \\
& Urozelotes trifidus Tuneva, 2003 \\
Linyphiidae & Hilaria excisa (O. Pickard-Cambridge, 1871) \\
& Piniphantes agnellus (Maurer \& Thaler, 1988) \\
& n. comb. \\
& Linyphia hortensis Sundevall, 1830 \\
& Pocadicnemis juncea Locket \& Millidge, 1953 \\
& Pardosa alacris (C. L. Koch, 1833) \\
& Pardosa mixta (Kulczyński, 1887) \\
& Pardosa pullata (Clerck, 1757) \\
& Vesubia jugorum (Simon, 1881) \\
Pycosidae & Philodromus vagulus Simon, 1875 \\
& Philodromus fuscolimbatus Lucas, 1846 \\
& Philodromus cespitum (Walckenaer, 1802) \\
& Thanatus atratus Simon, 1875 \\
& Attulus distinguendus (Simon, 1868) \\
& Heliophanus lineiventris Simon, 1868 \\
& Chrysso nordica (Chamberlin \& Ivie, 1947) \\
Salticidae & Dipoena torva (Thorell, 1875) \\
& Enoplognatha caricis (Fickert, 1876) \\
Theridiidae & Enoplognatha latimana Hippa \& Oksala, 1982 \\
& Episinus algiricus Lucas, 1846 \\
& Heterotheridion nigrovariegatum (Simon, 1873) \\
& Neottiura suaveolens (Simon, 1880) \\
& Misumena vatia (Clerck, 1757) \\
\hline &
\end{tabular}

susceptible to invasions of non-native species, as observed for many alien plant species, like Ailanthus altissima (Mill.) Swingle, Fallopia japonica (Houtt.) Ronse Decraene, Fallopia sachalinensis Ronse Decraene, Heracleum mantegazzianum Sommier \& Levier, Impatiens glandulifera Royle (Pyšek \& Prach 1993; Kowarik \& Säumel 2007; Gutiérrez et al. 2014). Many examples indicate that the altered dynamics of riparian ecosystems trigger the establishment and spread of invasive alien species, and the degree of the invasion is often positively associated with the level of disturbance (Décamps et al. 1995; Naiman \& Décamps 1997; Wissmar \& Beschta 1998; Hood \& Naiman 2000; Tickner et al. 2001; Cooper et al. 2003; Richardson et al. 2007).

Urozelotes trifidus is a gnaphosid species recently described and found only in the steppe zone of the South Urals, Russia (Tuneva 2003). This species was collected in the same habitat as $C$. nordica, that may lead to hypothesize an anthropogenic introduction also in this case. However, we can not exclude that this could be a rare native species previously overlooked in France.

Regarding chorotypes, more than half of the species collected (55\%) have a Palearctic distribution, while Holarctic and European elements share a percentage of $16 \%$. TuranicEuropean-Mediterranean species are represented by $6 \%$ of the total, while Mediterranean species are only $2 \%$ and Cosmopolitan 1\%. By contrast, Endemic species represent 4\% of the total (Fig. 15). These are all alpine species, and most of them were found above $2000 \mathrm{~m}$ a.s.l., in rocky lands and between boulders on mountain slopes. Among them, Vesubia jugorum (Simon, 1881), a large-sized lycosid occurring ex- 


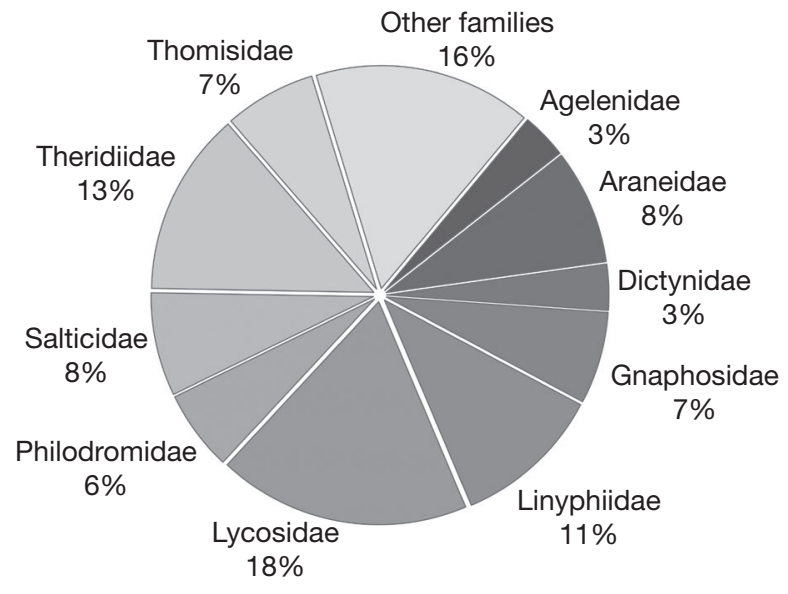

FIG. 14. - Species richness by family (in \%).

clusively in alpine rocky lands above $2300 \mathrm{~m}$, exhibits a very limited number of populations documented in literature in the South-Western Alps, mainly Maritime Alps (Mammola et al. 2016). The species is classified as Endangered and formally listed in the IUCN Red List of Threatened Species (IUCN 2018), on the basis of its limited geographic range and the estimate of the reduction of its natural habitat in the near future. The present work records its presence in the Barcelonnette area at $2361 \mathrm{~m}$ a.s.l., near to the Chapeau de Gendarme peak, thus representing one of westernmost data for the species, and the first record of the species for the area. Another endemic species, Drassodex simoni Hervé, Roberts \& Murphy, 2009 was found in the same locality. This species was already recorded for the Alpes-de-HauteProvence Department, where it was found in Lac d'Allos, Col de la Cayolle, Uvernet-Fours and Allos (Hervé et al. 2009), but never before in the Barcelonnette area. A further endemic species found in alpine rocky lands is Piniphanthes agnellus $\mathrm{n}$. comb., collected in talus caves on the pathway to Chapeau de Gendarme. In the same caves, the presence of Turinyphia clairi was further documented. This is a rare species, endemic of the SW-Alps and often associated with subterranean habitats (Isaia et al. 2017). Another remarkable endemic species restricted to the Western Alpine region, is Dysdera cribrata (Dysderidae), found in silver fir woods in the Bois de Gaudissart. This species was already known by the Alpes-de-Haute-Provence Department (Simon 1882, 1914 ; Isaia \& Chiarle 2015), but never recorded before in the Barcelonnette area.

The fieldwork carried out within the "Explor'Nature" event has been conducted in several habitat types within the study area. For each habitat, the sampling effort and the time spent for the collection of individuals were different. In order to maximise the sampling efficiency in a limited period of time, biological prospections were primarily focused on areas in which a higher species richness was a priori expected based on our expertise. Grasslands

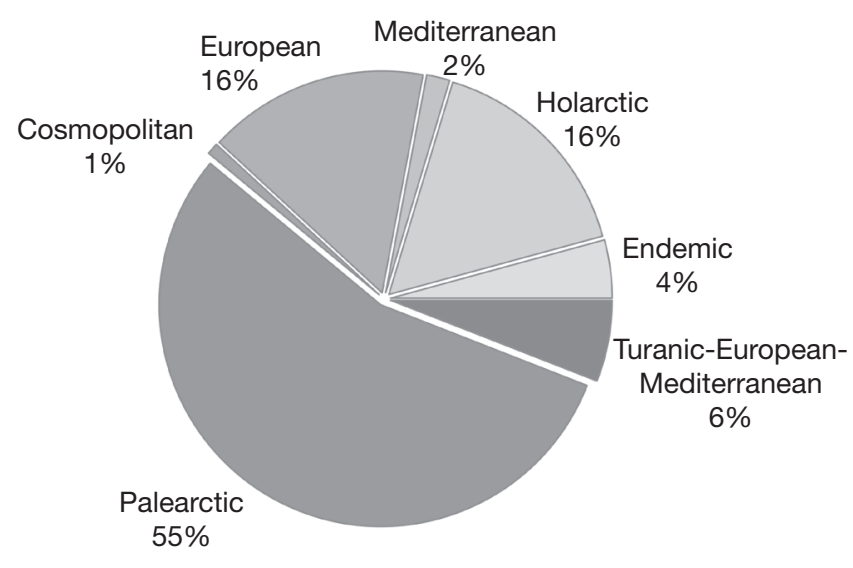

FIG. 15. - Species distribution. Groups of main chorotypes according to Table 2.

are in general regarded among the most biological diverse habitats, especially in term of arthropod diversity (Muller et al. 1998; Butaye et al. 2005; WallisDeVries \& van Swaay 2009). Among them, wet grasslands constitute an optimum habitat rich in spider species (Marc et al. 1999). Similarly, we also paid special attention to riparian habitats. As expected, wet grasslands were characterized by the highest species richness (29 species collected), followed by riparian habitats and shrublands, both with 25 species. In terms of abundance of specimens, wet grasslands were the richest macrohabitat (67 specimens collected), followed by riparian habitats (54 specimens), ruderal areas and rocky lands (39 specimens) (Fig. 16). Collections performed in riparian habitats revealed an array of interesting species, including two new species for France and several records of rare species, among which Brigittea latens (Dictynidae) and Ozyptila rauda (Thomisidae). Riparian habitats show the highest diversity of spider families, followed by shrublands and ruderal areas (Fig. 17). Rocky lands showed the highest diversity of endemic species, hosting three out of a total of five endemic species collected in the whole study area, namely Coelotes pabulator, D. simoni and V. jugorum. Wet grasslands and rocky lands hosted the highest richness of lycosids, while diversity of theridiids is higher in shrublands and wet grasslands (Fig. 17). Despite the low number of individuals collected, coniferous forests, broadleaved forests and mixed forests seem to be the most promising habitats in terms of the abundance/species richness ratio, and thus deserve particular attention in future studies. Variation in sampling efforts in the investigated macrohabitats directly affected the number of species found, preventing the possibility of comparisons among different habitats.

The "Explor'Nature Barcelonnette" has proved to be a valuable tool for improving the knowledge of local biodiversity, for investigating the biological richness of an area, up to now never explored from this perspective, and for raising public awareness of the need to conserve biodiver- 


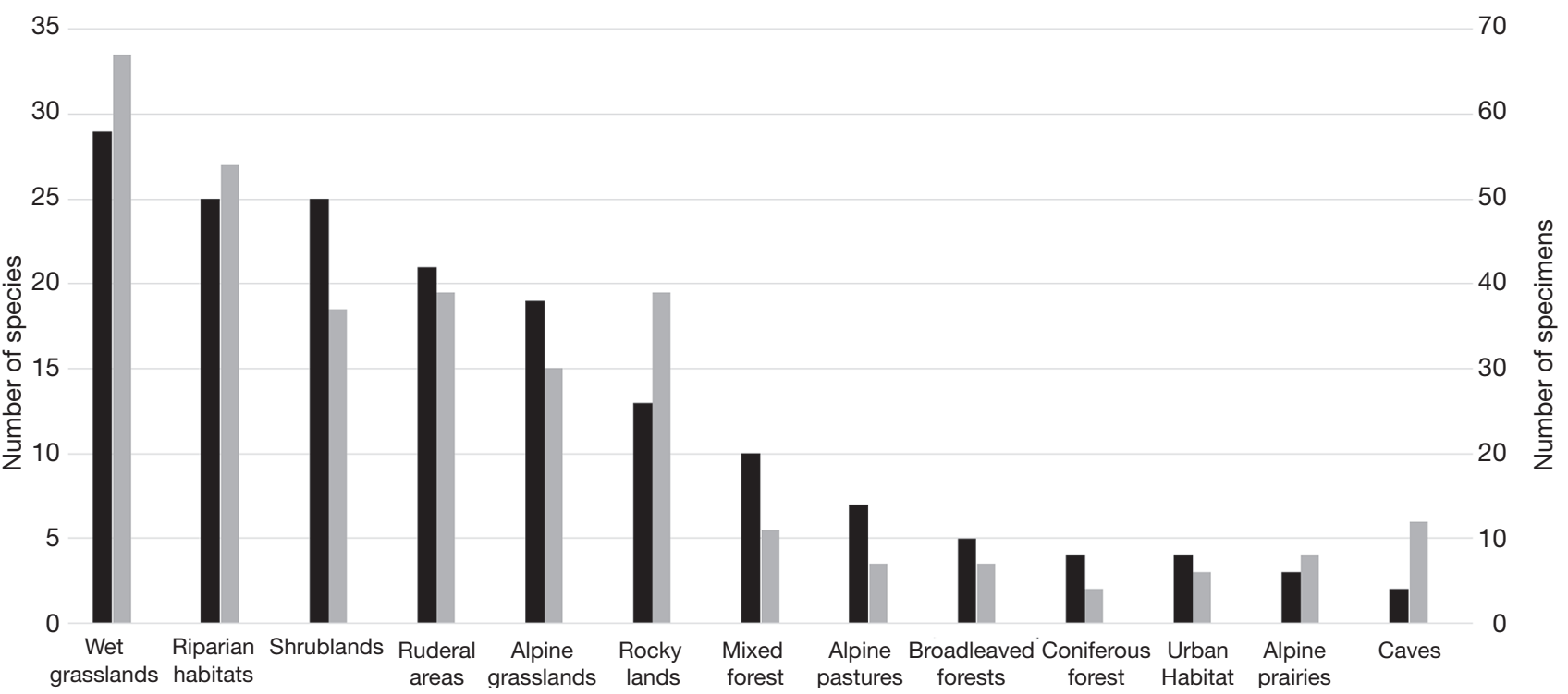

FIG. 16. - Number of species (black) and corresponding number of specimens (grey) for each macrohabitat.

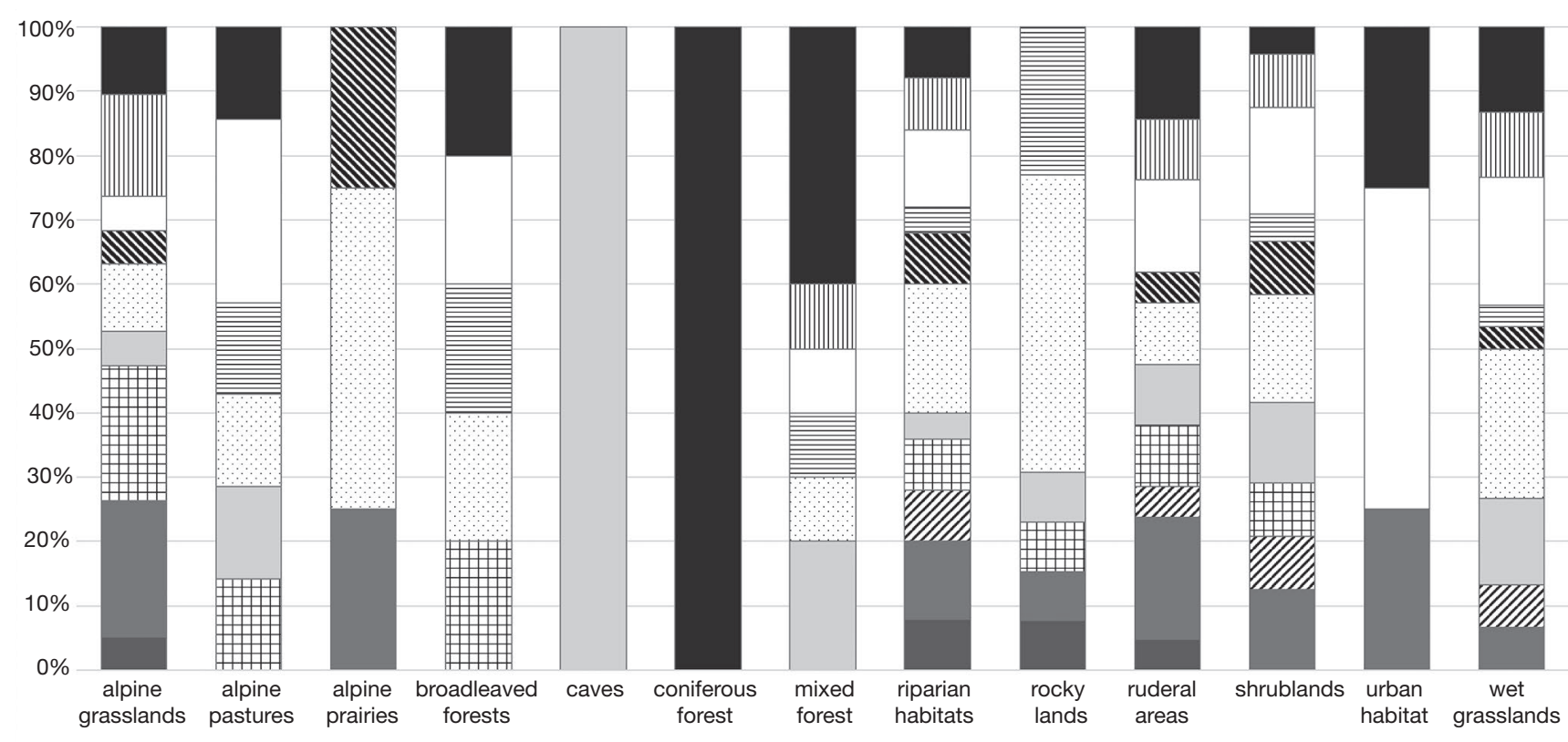

— Agelenidae $\square$ Araneidae ZDictynidae $\boxplus$ Gnaphosidae $\square$ Linyphiidae $:$ Lycosidae $\mathbf{S P h i l o d r o m i d a e ~} \equiv$ Salticidae $\square$ Theridiidae $\mathbb{m}$ Thomisidae $\square$ Other families

FIG. 17. - Species richness by family (in \%) in the most representative macrohabitats.

sity. Faunal inventories are essential for analyses of species distributions, relationships between local and regional diversity, patterns of endemism, and for the identification of diversity hot-spots, vulnerable habitats, and priority sites for conservation (Doak \& Mills 1994; Haila \& Margules 1996; Summerville et al. 2004; Summerville \& Crist 2005). As far as spiders are concerned, in recent years there have been similar examples of spider inventories, aimed at uncover- ing the spider diversity in a specific region (Hore \& Uniyal 2008; Haddad \& Russell-Smith 2010; Rubio 2016; Cardoso et al. 2017; Lamont et al. 2017). The presence of rare and endemic species, including a red-listed species, and new records for France, highlights the importance of this kind of events, aiming to increase the knowledge of the biology and the ecology of various animal taxa, and to implement such data in conservation programs. 


\section{Acknowledgements}

Special thanks are due to all photographers (see figure captions for credits), and to the Mercantour National Park for the permission to use spider photographs. We are grateful to Julien Andrieu, Francine Brondex and Francesco Tomasinelli for helping in the samplings, and to the staff of the Mercantour National Park for the logistic support during the event. We thank Christophe Hervé and Paolo Pantini for their valuable comments that significantly improved the quality of the manuscript. Moreover, a special acknowledgement is due to Christophe Hervé for providing expert opinion on the identification of Urozelotes trifidus, and for making available further data on the distribution of Piniphantes agnellus n. comb.

\section{REFERENCES}

AzHEGANOVA N. S. 1968. - A brief guide to spiders (Aranei) of the forest and forest-steppe zone of the USSR (in Russian). Izdatelstvo Nauka, Leningrad, 149 p.

Bosmans R. 1997. - Revision of the genus Zodarion Walckenaer, 1833 in the Iberian Peninsula and Balearic Islands (Araneae, Zodariidae). Eos 69: 115-142.

Bosmans R. \& OGER P. 2018.- On two cases of male dimorphism in dwarf spiders (Araneae: Linyphiidae). Arachnologische Mitteilungen 55 (1): 52-56. https://doi.org/10.30963/aramit5509

Bosmans R. \& VAN KeER J. 1999. — The genus Enoplognatha Pavesi, 1880 in the Mediterranean region (Araneae: Theridiidae). Bulletin of the British Arachnological Society 11 (6): 209-241.

Breituing R., Bauer T., Schäfer M., Morano E., Barrientos J. A. \& Blick T. 2016. — Phantom spiders 2: More notes on dubious spider species from Europe. Arachnologische Mitteilungen 52: 50-77. https://doi.org/10.5431/aramit5209

BRIGNOLI P. M. 1978. - Quelques notes sur les Agelenidae, Hahniidae, Oxyopidae et Pisauridae de France et d'Espagne (Araneae). Revue Suisse de zoologie 85 (2): 265-294. https://doi. org/10.5962/bhl.part.82231

Butaye J., Adriaens D. \& Honnay O. 2005. - Conservation and restoration of calcareous grasslands: a concise review of the effects of fragmentation and management on plant species. Biotechnology, Agronomy, Society and Environment 9: 111-118.

Cardoso P., HeikKinen L., Jalkanen J., Kohonen M., Leponiemi M., Mattila L., Ollonen J., Ranki J., Virolainen A., Zhou X. \& PAJUnen T. 2017. — Standardized spider (Arachnida, Araneae) inventory of Hankoniemi, Finland. Biodiversity Data Journal 5: e21010. https://doi.org/10.3897/BDJ.5.e21010

CHARITONOv D. E. 1950. - Pauki-Araneina. Zhivotnii mir SSSR, zona stepei 3: 441-451.

Cooper D. J., Andersen D. C. \& Chimner R. A. 2003. - Multiple pathways for woody plant establishment on floodplains at local to regional scales. Journal of Ecology 91: 182-196. https:// doi.org/10.1046/j.1365-2745.2003.00766.x

Décamps H., Planty-Tabacchi A. M. \& Tabacchi E. 1995. Changes in the hydrological regime and invasions by plant species along riparian systems of the Adour River, France. Regulated Rivers: Research \& Management 11:23-33. https://doi.org/10.1002/ rrr.3450110104

DeEleman-Reinhold C. L. \& DeEleman P. R. 1988. — Révision des Dysderinae (Araneae, Dysderidae), les espèces méditerranéennes occidentales exceptées. Tijdschrift voor Entomologie 131: 141-269.

DOAK D. F. \& MiLLS L. S. 1994. - A Useful Role for Theory in Conservation. Ecology 75: 615-626. https://doi.org/10.2307/1941720

Dondale C. D., Redner J. H. \& Marusik Y. M. 1997. — Spiders (Araneae) of the Yukon, in DANKS H. V. \& Downes J. A. (eds), Insects of the Yukon. Biological Survey of Canada (Terrestrial
Arthropods), Ottawa: 73-113.

DrEsCO E. 1962. — Araignées capturées en France dans des grottes ou des cavités souterraines. Annales de Spéléologie 17 (1): 177-193.

DrESCO E. 1966. —Étude de quelques espèces d'araignées du genre Nesticus (Fam. Nesticidae). Annales de Spéléologie 21 (3): 795-813.

Dresco E. 1987. —Étude des Leptoneta: Leptoneta (Araneae, Leptonetidae) du sud-est de la France. Bulletin du Muséum national d'histoire naturelle (4) 9 (3): 633-650.

Dresco E. \& HuberT M. 1975. - Araneae Speluncarum Galliae. II. Annales de Spéléologie 30 (3): 441-450.

Flageollet J.-C., Maquaire O., Martin B. \& Weber D. 1999. Landslides and climatic conditions in the Barcelonnette and Vars basins Southern French Alps, France. Geomorphology 30: 65-78. https://doi.org/10.1016/S0169-555X(99)00045-8

Greiving S. \& Angignard M. 2014. - Disaster Mitigation by Spatial Planning, in VAN Asch T., Corominas J., GreIVING S., Malet J. P. \& STerlacchini S. (eds), Mountain Risks: From Prediction to Management and Governance. Advances in Natural and Technological Hazards Research. Dordrecht, Springer 34: 287 302. https://doi.org/10.1007/978-94-007-6769-0

Gutiérrez M., Ranera E., Novo M., Fernández R. \& Trigo D. 2014. - Does the invasion of the exotic tree Ailanthus altissima affect the soil arthropod community? The case of a riparian forest of the Henares River (Madrid). European Journal of Soil Biology 62: 39-48. https://doi.org/10.1016/j.ejsobi.2014.02.010

HADDAD C. R. \& RuSSELL-SMith A. 2010. — Spider family composition and species richness patterns in two savannah habitats along the eastern coastal plain of Africa. African Journal of Ecology 48: 418-427. https://doi.org/10.1111/j.1365-2028.2009.01128.x

Haila Y. \& Margules C. R. 1996. - Survey research in conservation biology. Ecography 19: 323-331. https://doi. org/10.1111/j.1600-0587.1996.tb00243.x

Hervé C., Roberts M. J. \& Murphy J. A. 2009. - A taxonomic revision of the genus Drassodex Murphy, 2007 (Araneae: Gnaphosidae). Zootaxa 2171: 1-28. https://doi.org/10.5281/ zenodo. 189206

Hood W. G. \& Naiman R. J. 2000. — Vulnerability of riparian zones to invasion by exotic vascular plants. Plant Ecology 148 : 105-114. https://doi.org/10.1023/A:1009800327334

Hore U. \& UnIYAL V. P. 2008. - Diversity and composition of spider assemblages in five vegetation types of the Terai Conservation Area, India. Journal of Arachnology 36: 251-258. https:// doi.org/10.1636/CT07-53.1

ISAIA M. \& CHIARLE A. 2015. - Taxonomic notes on Cybaeus vignai Brignoli, 1977 (Araneae, Cybaeidae) and Dysdera cribrata Simon, 1882 (Araneae, Dysderidae) from the Italian Maritime Alps, in Daugeron C., Deharveng L., Isaia M., Villemant C. \& JudsON M. (eds), Mercantour/Alpi Marittime All Taxa Biodiversity Inventory. Zoosystema 37 (1): 45-56. https://doi.org/10.5252/ z2015n1a3

Isaia M., PASChetTA M. \& Chiarle A. 2015. - Annotated checklist of the spiders (Arachnida, Araneae) of the Site of Community Importance and Special Area of Conservation "Alpi Marittime" (NW Italy), in DAUgeron C., DeHARVEng L., IsAia M., VILLEMANT C., Judson M. (eds), Mercantour/Alpi Marittime All Taxa Biodiversity Inventory. Zoosystema 37 (1): 57-114. https:// doi.org/10.5252/z2015n1a4

Isaia M., Mammola S., Mazzuca P., Arnedo M. A. \& Pantini P. 2017. - Advances in the systematics of the spider genus Troglohyphantes (Araneae, Linyphiidae). Systematics and biodiversity 15 (4): 307-326. https://doi.org/10.1080/14772000.2016.1254304

IUCN 2018. — The IUCN Red List of Threatened Species, online at http://www.iucnredlist.org. Planned update 28.06.2018.

Jeannel R. 1926. - Faune cavernicole de la France. Éditions Paul Lechevalier, Paris, 334 p.

KNOFLACH B. 1999 - The comb-footed spider genera Neottiura and Coleosoma in Europe (Araneae, Theridiidae). Mitteilungen der Schweizerischen Entomologischen Gesellschaft 72 (3-4): 341- 
371. https://doi.org/10.5169/seals-402764

Knoflach B., Rollard C. \& Thaler K. 2009. - Notes on Mediterranean Theridiidae (Araneae) - II. ZooKeys 16: 227-264. https://doi.org/10.3897/zookeys.16.237

KOWARIK I. \& SÄUMEL I. 2007. - Biological flora of Central Europe: Ailanthus altissima (Mill.) Swingle. Perspectives in Plant Ecology, Evolution and Systematics 8 (4): 207-237. https://doi. org/10.1016/j.ppees.2007.03.002

Kraus O. \& BaUR H. 1974. - Die Atypidae der West-Paläarktis. Systematik, Verbreitung und Biologie (Arach.: Araneae). Abhandlungen und Verhandlungen des Naturwissenschaftlichen Vereins in Hamburg (NF) 17: 85-116.

Lamont S. M., Vink C. J., Seldon D. S. \& Holwell G. I. 2017. - Spider diversity and community composition in native broadleaf-podocarp forest fragments of northern Hawke's Bay, New Zealand. New Zealand Journal of Zoology 44 (2): 129-143. https://doi.org/10.1080/03014223.2017.1281320

Le Peru B. 2007. - Catalogue et répartition des araignées de France. Revue Arachnologique 16: 1-458.

LE Peru B. 2011. - The spiders of Europe, a synthesis of data: Volume 1 Atypidae to Theridiidae. Mémoires de la Société Linnéenne de Lyon 2: 1-522.

LUCZACK J. \& VEDOVINI A. 1964. — Note préliminaire sur les Araignées cavernicoles des environs de Marseille. Vie et Milieu 15 (3): 709-714.

LugetTi G. \& Tongiorgi P. 1969. - Ricerche sul genere Alopecosa Simon (Araneae-Lycosidae). Atti della Società toscana di Scienze Naturali 76: 1-100.

Mammola S., Milano F., Cardoso P. \& Isaia M. 2016. — Species conservation profile of the alpine stenoendemic spider Vesubia jugorum (Araneae, Lycosidae) from the Maritime Alps. Biodiversity Data Journal4: e10527. https://doi.org/10.3897/BDJ.4.e10527

Mammola S., Cardoso P., Ribera C., Pavlek M. \& isaia M. 2018. - A synthesis on cave-dwelling spiders in Europe. Journal of Zoological Systematics and Evolutionary Research 56 (3): 301 316. https://doi.org/10.1111/jzs.12201

Marc P., Canard A. \& Ysnel F. 1999. - Spiders (Araneae) useful for pest limitation and bioindication, Agriculture, Ecosystems and Environment 74: 229-273. https://doi.org/10.1016/S01678809(99)00038-9

MARUSiK Y. M., LogunOv D. V. \& KopOnen S. 2000. — Spiders of Tuva, South Siberia. Institute for Biological Problems of the North, Russian Academy of Sciences Far East Branch, Magadan, 252 p.

Maurer R. \& Thaler K. 1988. - Über bemerkenswerte Spinnen des Parc national du Mercantour (F) und seiner Umgebung (Arachnida: Araneae). Revue Suisse de Zoologie 95: 329-353. https://doi.org/10.5962/bhl.part.79655

Metzner H. 1999. - Die Springspinnen (Araneae, Salticidae) Griechenlands. Andrias 14: 1-279.

MülLER H.-G. 1985. - Faunistische Notizen über Spinnen aus der Provence und den französischen Alpen (Arachnida: Araneida). Neue Entomologische Nachrichten 17: 43-51.

Muller S., Dutoit T., Alard D. \& Grévilliot F. 1998. — Restoration and Rehabilitation of Species-Rich Grassland Ecosystems in France: a Review. Restoration Ecology 6: 94-101. https://doi. org/10.1046/j.1526-100x.1998.06112.x

NAIMAN R. J. \& DÉCAMPS H. 1997. - The Ecology of interfaces: Riparian Zones. Annual Review of Ecology and Systematics 28: 621-658. https://doi.org/10.1146/annurev.ecolsys.28.1.621

Nentwig W., Blick T., Gloor D., HÄnggi A. \& Kropf C. 2018. Spiders of Europe. Version 05.2018. https://doi.org/10.24436/1

PANTINI P. \& IsAiA M. 2018. — Checklist of the Italian spiders. Version June 2018. https://www.museoscienzebergamo.it/web/ index.php?option $=$ com_content $\&$ view=article\&id $=475:$ checkl ist-italian-spiders\&catid=96: checklist-ragni-italiani\&Itemid $=94$

PeYerimhoff P. 1906. - Recherches sur la faune cavernicole des Basses-Alpes. Annales de la Société entomologique de France 75: 203-222.
PiCKARD-CAMBRIDGE O. 1875. - On some new species of Erigone. Proceedings of the Zoological Society of London 43 (2): 190-335. https://biodiversitylibrary.org/page/28501626

PYšEK P. \& PRACH K. 1993. - Plant invasions and the role of riparian habitats: a comparison of four species alien to Central Europe. Journal of Biogeography 20 (4): 413-420. https://doi. org/10.2307/2845589

ŘEZÁČ M., KRÁL J. \& PeKÁR S. 2008. — The spider genus Dysdera (Araneae, Dysderidae) in central Europe: Revision and natural history. The Journal of Arachnology 35: 432-462. https://doi. org/10.1636/H06-38.1

Richardson D. M., Holmes P. M., Esler K. J., Galatowitsch S. M., Stromberg J. C., Kirkman S. P., PYšEK P. \& HobbS R. J. 2007. - Riparian vegetation: degradation, alien plant invasions, and restoration prospects. Fisheries, Wildlife, and Conservation Biology 13: 126-139. https://doi.org/10.1111/j.13669516.2006.00314.x

RoberTs M. J. 1995. - Spiders of Britain \& Northern Europe. HarperCollins Publishers, London, 232 p.

RUBio G. D. 2016. - Using a jumping spider fauna inventory (Araneae: Salticidae) as an indicator of their taxonomic diversity in Misiones, Argentina. Revista de Biología Tropical 64: 875-883. https://doi.org/10.15517/rbt.v64i2.19722

SaARisto M. I. \& TANASEVITCH A. V. 1993. - Notes on the systematics of the spider genus Lepthyphantes Menge (Aranei Linyphiidae Micronetinae). Arthropoda Selecta 2: 55-61.

SAARISTO M. I. \& TANASEVITCH A. V. 1996. — Redelimitation of the subfamily Micronetinae Hull, 1920 and the genus Lepthyphantes Menge, 1866 with descriptions of some new genera (Aranei, Linyphiidae). Berichte des Naturwissenschaftlich-Medizinischen Vereins in Innsbruck 83: 163-186.

Simon E. 1874a. - Les Arachnides de France. Volume 1. Roret, Paris, 266 p.

SimON E. 1874b. — Études arachnologiques. 3e mémoire. V. Révision des espèces européennes de la famille des Sparassidae. Annales de la Société entomologique de France (5) 4: 243-279.

SimON E. 1875a. - Les Arachnides de France. Volume 2. Roret, Paris, $350 \mathrm{p}$

SimON E. 1875b. - Descriptions de deux nouvelles espèces: Philodromus albopictus et Dictyna sedilloti. Annales de la Société entomologique de France (bulletin) (5) 5: CXLIX-CLI.

SIMON E. 1875c. - Descriptions de nouvelles espèces d'Arachnides d'Europe. Annales de la Société entomologique de France (bulletin) 5 (5): XCII-XCV.

Simon E. 1876. - Les Arachnides de France. Volume 3. Roret, Paris, $364 \mathrm{p}$.

Simon E. 1878. - Les Arachnides de France. Volume 4. Roret, Paris,334 p.

SimON E. 1879. - Arachnides nouveaux de France, d'Espagne et d'Algérie. Bulletin de la Société zoologique de France 4: 251-263.

SimOn E. 1881. — Les Arachnides de France. Volume 5 (1). Roret, Paris: $1-179$.

SIMON E. 1882. - Études arachnologiques. 13e mémoire. XX. Descriptions d'espèces et de genres nouveaux de la famille des Dysderidae. Annales de la Société entomologique de France (6) 2: 201-240.

SimON E. 1884a. - Les Arachnides de France. Volume 5 (2). Roret, Paris: $181-420$.

SimON E. 1884b. - Les Arachnides de France. Volume 5 (3). Roret, Paris: 421-885.

SimON E. 1898. - Étude sur les Arachnides de la région des Maures (Var). La Feuille des Jeunes Naturalistes (3) 29 (337): 2-4.

SIMON E. 1913. - Araneae et Opiliones (4e série), in DE LacaZe-Duthiers H. (ed.), Biospeologica. XXX. Archives de zoologie expérimentale et générale. Volume 11. Paris, 52 (2): 359-386.

SimON E. 1914. - Les Arachnides de France. Volume 6 (1). Roret, Paris: 1-308. 
Simon E. 1926. - Les Arachnides de France. Volume 6 (2). Roret, Paris: 309-532.

SimON E. 1929. - Les Arachnides de France. Volume 6 (3). Roret, Paris: 533-772.

SimON E. 1932. - Les Arachnides de France. Volume 6 (4). Roret, Paris: 773-978.

SimON E. 1937. - Les Arachnides de France. Volume 6 (5). Roret, Paris: $979-1298$.

SIMON U. 1997. - On the biology of Dipoena torva (Araneae: Theridiidae). Arachnologische Mitteilungen 13: 29-40. https:// doi.org/10.5431/aramit1303

Stoch F. \& Vigna Taglianti A. 2005. - I corotipi della fauna italiana, in RUFFO S. \& STOCH F. (eds), Checklist e distribuzione della fauna italiana. Memorie del Museo Civico di Storia Naturale di Verona, 2 serie, Sezione Scienze della Vita 16: 25-28.

Summerville K. S. \& CRIST T. O. 2005. - Temporal patterns of species accumulation in a survey of Lepidoptera in a beech-maple forest. Biodiversity \& Conservation 14 (14): 3393-3406. https:// doi.org/10.1007/s10531-004-0546-x

Summerville K. S., RitTer L. M. \& CRIST T. O. 2004. - Forest moth taxa as indicators of lepidopteran richness and habitat disturbance: a preliminary assessment. Biological Conservation 116 (1): 9-18. https://doi.org/10.1016/S0006-3207(03)00168-X

SZINETÁr C., HORVÁTH R. \& EICHARDT J. 2002 - Chrysso nordica (Theridiidae, Araneae) found in Eastern Hungary is a new spider species for Central Europe in SAMU F. \& SzInETÁr C. (eds) European Arachnology 2002. Plant Protection Institute and Berzsenyi College, Budapest: 303-307.

Tickner D. P., Angold P. G., Gurnell A. M. \& Mountford. J. O. 2001. - Riparian plant invasions: hydrogeomorphological control and ecological impacts. Progress in Physical Geography 25: 22-52. https://doi.org/10.1177/030913330102500102

TUNEVA T. K. 2003 - Urozelotes trifidus sp.n. - a new species of gnaphosid spiders (Aranei, Gnaphosidae) of steppe zone of the south Urals. Euroasian Entomological Journal 2 (2): 95-96.

van Westen C. J., Kappes M. S., Quan Luna B., Frigerio S., Glade T. \& Malet J. P. 2014. - Medium-Scale Multi-hazard Risk Assessment of Gravitational Processes, in VAN AsCH T.,
Corominas J., Greiving S., Malet J. P. \& Sterlacchini S. (eds), Mountain Risks: From Prediction to Management and Governance. Advances in Natural and Technological Hazards Research, Dordrecht, Springer, 34: 201-232. https://doi.org/10.1007/97894-007-6769-0

Vigna Taglianti A., Audisio P. A., Belfiore C., Biondi M., Bologna M. A., Carpaneto G. M., De Biase A., De Felici S., Piattella E., Racheli T., Zapparoli M. \& Zoia S. 1993. Riflessioni di gruppo sui corotipi fondamentali della fauna W-Paleartica ed in particolare italiana. Biogeographia 16: 159-179.

Vigna Taglianti A., Audisio P. A., Biondi M., Bologna M. A., Carpaneto G. M., De Biase A., Fattorini S., Piattella E., Sindaco R., Venchi A. \& Zapparoli M. 1999. - A proposal for a chorotype classification of the Near East fauna, in the framework of the Western Palearctic region. Biogeographia 20: 31-59.

WallisDeVRIES M. F. \& VAN SWAAY C. A. 2009. - Grasslands as habitats for butterflies in Europe, in VEEN P., JEFFERSON R., DE SMIDT J., VAN DER STRAATEN J. (eds), Grasslands in Europe of high nature value. KNNV Publishing, Zeist: 27-34.

White W. B. \& Culver D. C. 2012. - Cave, definition of, in White W. B. \& Culver D. C. (eds), Encyclopedia of Caves (Second Edition). Elsevier, Amsterdam: 103-107.

WieHLE H. 1953. - Spinnentiere oder Arachnoidea (Araneae), IX. Orthognatha-Cribellata-Haplogynae, Entelegynae (Pholcidae, Zodariidae, Oxyopidae, Mimetidae, Nesticidae), in DAHL F., DAHL M. \& BisChOfF H. (Hrsg.), Die Tierwelt Deutschlands 42. G. Fischer, Jena, 150 p.

WissMAR R. C. \& BESCHTA R. L. 1998. - Restoration and management of riparian ecosystems: a catchment perspective. Freshwater Biology 40: 571-585. https://doi.org/10.1046/j.13652427.1998.00383.x

World Spider Catalog 2018. — World Spider Catalog. Natural History Museum Bern, online at http://wsc.nmbe.ch, version 19.0, accessed on 28.02.2018. https://doi.org/10.24436/2

Wunderlich J. 1995. - Zu Taxonomie und Biogeographie der Arten der Gattung Oecobius Lucas 1846, mit Neubeschreibungen aus der Mediterraneis und von der Arabischen Halbinsel (Arachnida: Araneae: Oecobiidae). Beiträge zur Araneologie 4: 585-608. 